\title{
From Rust to Quantum Biology: The Role of Iron in Retina Physiopathology
}

\author{
Emilie Picard ${ }^{1, *(\mathbb{D}}$, Alejandra Daruich ${ }^{1,2}{ }^{\text {, Jenny Youale }}{ }^{1}$, Yves Courtois ${ }^{1}{ }^{\mathbb{D}}$ and \\ Francine Behar-Cohen ${ }^{1,3}$ \\ 1 Centre de Recherche des Cordeliers, INSERM, Sorbonne Université, USPC, Université Paris Descartes, \\ Team 17, F-75006 Paris, France; adaruich.matet@gmail.com (A.D.); youale.j@hotmail.fr (J.Y.); \\ courtois.yves@numericable.com (Y.C.); francine.behar@gmail.com (F.B.-C.) \\ 2 Ophthalmology Department, Necker-Enfants Malades University Hospital, APHP, 75015 Paris, France \\ 3 Ophtalmopole, Cochin Hospital, AP-HP, Assistance Publique Hôpitaux de Paris, 24 rue du Faubourg \\ Saint-Jacques, 75014 Paris, France \\ * Correspondence: picardemilie@gmail.com; Tel.: +331-44-27-81-82
}

Received: 17 February 2020; Accepted: 9 March 2020; Published: 13 March 2020

check for updates

\begin{abstract}
Iron is essential for cell survival and function. It is a transition metal, that could change its oxidation state from $\mathrm{Fe}^{2+}$ to $\mathrm{Fe}^{3+}$ involving an electron transfer, the key of vital functions but also organ dysfunctions. The goal of this review is to illustrate the primordial role of iron and local iron homeostasis in retinal physiology and vision, as well as the pathological consequences of iron excess in animal models of retinal degeneration and in human retinal diseases. We summarize evidence of the potential therapeutic effect of iron chelation in retinal diseases and especially the interest of transferrin, a ubiquitous endogenous iron-binding protein, having the ability to treat or delay degenerative retinal diseases.
\end{abstract}

Keywords: iron; retina; transferrin

\section{Introduction}

Iron is a major element in biology. Besides its well-known role in prebiotic conditions after the rise of oxygen in the atmosphere, its insolubility led to the development of many mechanisms to allow the primitive cells and organisms to use it. They are driven by the transition of ferrous iron $\left(\mathrm{Fe}^{2+}\right)$ to ferric iron $\left(\mathrm{Fe}^{3+}\right)$ involving an electron which is particularly available and is the basis of vital functions and dysfunctions in the organs.

In this review, we analyze several of the well-known or recently discovered functions of iron in the eye, mainly in the retina, and the most promising approaches to regulate it and improve a large number of its negative side effects which can lead to vision impairment. We will focus on the main functions of transferrin (TF) as a partner in the systemic and cellular mechanisms that underlie the regulation of iron homeostasis and its disorders.

\section{The Retina Structure and Retinal Oxygen Supply}

The eye is a complex and confined organ formed by different compartments and structures essential for the transmission and focus of photons from the cornea to the photoreceptors (PRs), which convert them into an electrical signal transmitted to the brain. The neural retina comprises the PRs, cones, rods, the interneurons, the ganglion cells, the glial cells such as retinal Müller's glial cells (MGC), astrocytes, and microglia (Figure 1). The retina is vascularized by two separate vascular systems, the retinal vessels, branches of the central retinal artery that vascularize the inner retinal layers, and the choroidal vessels, branches of the ciliary arteries that supply the avascular PR layer through the retinal 
pigment epithelium (RPE) cells. In primates and human, visual acuity, photopic vision, and color vision are ensured by the macula, a highly specialized retinal area that comprises less than $5 \%$ of the total retinal surface, located at the center of the visual axis. The center of the macula, the fovea, is devoid of retinal vessels and composed exclusively of cones and MGC cells.

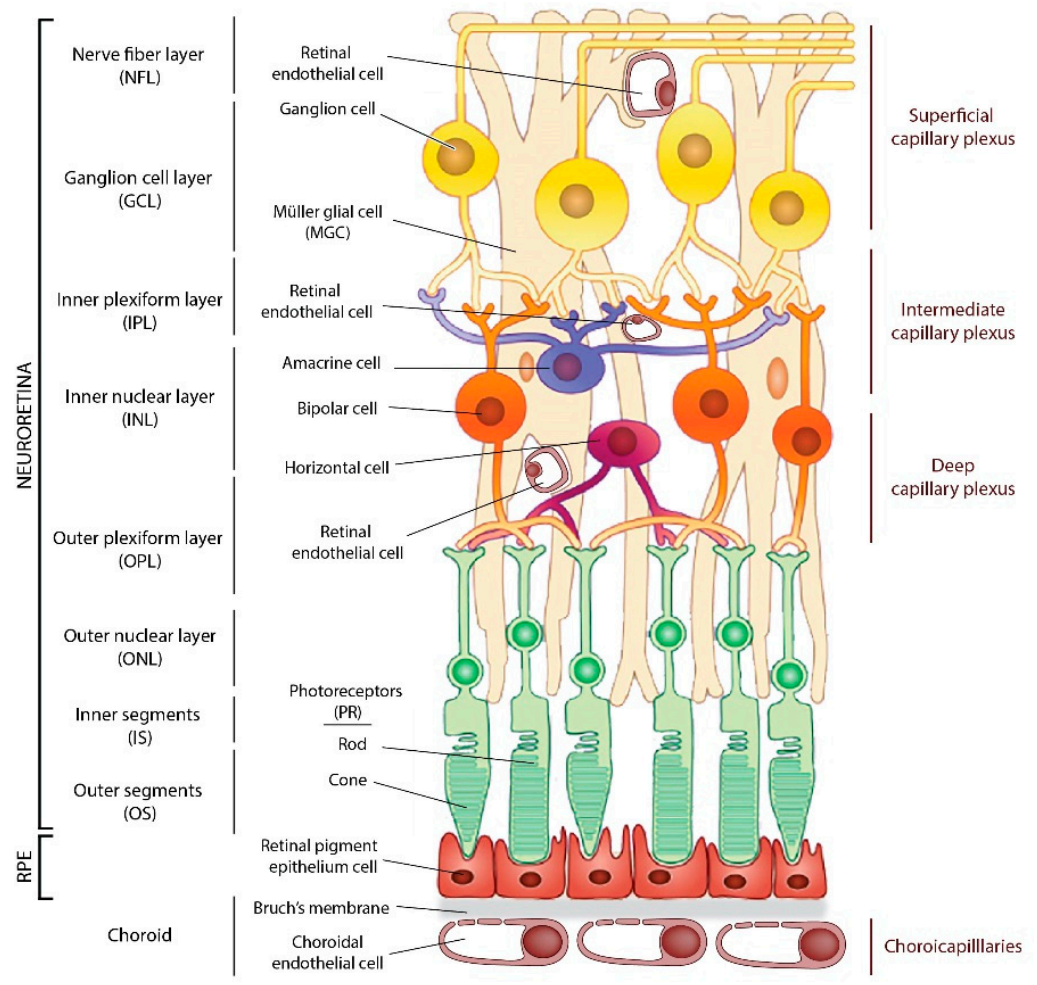

Figure 1. Schematic drawing of the cellular components of the retina. Legend Figure 1: There are three retinal vascular plexuses tightly coordinated with retinal neurons and a choroid plexus underlying RPE. GCL: Ganglion cell layer; NFL: Nerve fiber layer; INL: Inner nuclear layer; IPL: Inner plexiform layer; MGC: Müller glial cell; ONL: Outer nuclear layer; OPL: Outer plexiform layer; OS: Outer segments; IS: Inner segments; PR: Photoreceptors; RPE, retinal pigment epithelium.

The retina is separated from the circulation by two blood-retinal barriers (BRB). The inner BRB consists of a neuro-glio-vascular complex formed by tight junctions between endothelial cells of the retinal capillaries, pericytes, astrocytes, MGC, and microglia [1]. The outer BRB is formed by the tight-junction monolayer of RPE cells that are in close contact with the choriocapillaries, which control exchanges through diaphragmed fenestrations [1]. Oxygen is the most supply-limited metabolite in the retina [2]. Its supply to the retina is ensured by the choroid, which provides oxygen to the outer retina, whilst the retinal circulation provides the oxygen requirements of the inner retina. In normal condition, the level of oxygen tension $\left(\mathrm{Po}_{2}\right)$ in the outer retina is ten times lower than in the inner retina [3]. Oxygen and glucose consumption are metabolized to lactate, while aerobic glycolysis dominates energy production in the outer retina. Several factors modify $\mathrm{Po}_{2}$ level and utilization at the cellular level: the retinal depth, the light, and hyperoxia [4,5]. PRs have almost all mitochondria in their inner segments far from blood vessels. Light decreases oxygen utilization on the outer retina as much as by a factor of two and increase $\mathrm{Po}_{2}$. Hyperoxia dramatically increases $\mathrm{Po}_{2}$ in the retina with the increase higher in outer retina compared to inner retina. The development and maintenance of retinal vasculature is regulated by $\alpha$ subunits of hypoxia-inducible factor (HIF), which induce genes required for retinal homeostasis, such as vascular endothelial growth factor (VEGF) under hypoxic conditions [6]. HIF proteins, which act as regulators of oxygen homeostasis, also depend on iron for their activity, and they regulate genes involved in iron metabolism [7]. Hyperoxia is deleterious to the outer retina as the oxygen leads to the formation of reactive oxygen species (ROS) according to the 
Fenton and Haber-Weiss reaction catalyzed by iron to generate $\mathrm{RO}^{\circ}$ radical (review in [3]). Iron and oxygen are thus closely linked in retinal metabolism in health and disease conditions.

\section{Iron Homeostasis in the Retina}

\subsection{Distribution of Iron in the Retina}

Iron is widely and unevenly distributed throughout the adult rat retina. The highest concentrations of iron were observed by proton-induced X-ray emission in the choroid, the RPE, and the inner segments of the PR. PR outer segments also contain iron, as inclusions inside the discs [8]. Iron and iron-related parameter (total iron binding capacity, TF and TF saturation percentage) distribution in the eye are different between diurnal and nocturnal animals. In cow and pig retina, iron concentration is higher than in rat retina, suggesting that the nocturnal habit of living could influence iron-related parameters in the retina [9]. The iron level also varies during retinal development and aging. Moos et al. have shown that in rats, iron entry is very high during retinal development and maturation, then decreases in adulthood, and increases again with aging [10]. In rodents, there are gender and strain-specific influences on iron regulation in the neural retina [11]. Human sex-associated differences in iron levels have also been reported, women having more retinal iron than men at all ages [12]. With aging, iron deposits are found in the RPE/choroid complex in rats and in the stroma of the choroid in non-human primate regardless of serum iron concentration [13]. Increased iron levels in the retina have also been reported in human eyes with age [12]. In rodent eyes, both neural retina and RPE/choroid present an increase of iron concentration which is associated with modifications of iron-related proteins mRNA and protein levels $[14,15]$.

\subsection{Proteins Involved in Retinal Iron Homeostasis}

\subsubsection{General Iron Homeostasis}

Under physiological conditions, almost all non-heme iron $\left(\mathrm{Fe}^{3+}\right)$ in the circulation is transported bound to TF (transferrin-bound iron: TBI) with high affinity (for review on cellular iron metabolism [16]). At cellular level, the TF with two $\mathrm{Fe}^{3+}$ (holo-TF) is bound by its receptor (TFR1), and the complex is internalized. The $\mathrm{Fe}^{3+}$ is released from TF in the endosome under the effect of acidification through the action of an ATP-dependent proton pump. Iron is then reduced into the ferrous form, $\mathrm{Fe}^{2+}$, by endosomal ferrireductase six transmembrane epithelial antigen of the prostate 3 (STEAP3) and exported by divalent metal transporter 1 (DMT1) in the cytosol where it contributes to the labile iron pool (LIP). In case of iron overload, TF is saturated with iron, and the non-transferrin-bound ferrous iron (NTBI) could be up-taken by iron importers such as the ZRT/IRT-like proteins (ZIPs) or DMT1 and joined intracellular LIP. The LIP consists of a transitory pool of iron species associated with a variety of ligands with low affinity (citrate, phosphate, inorganics irons) and easily oxidized, in transit to be distributed to the organelles (in particularly in mitochondria or nucleus) for cell metabolism in iron requiring proteins, stored or released.

In non-erythroid cells, the majority of iron is stored in ferritin (FT). Composed of 24 subunits of both heavy (HFT) and light (LFT) chains, FT forms a tissue-specific heterocomplex which can store up to $4500 \mathrm{Fe}^{3+}$. $\mathrm{Fe}^{2+}$ from LIP is transported to FT by Poly(rC)-binding proteins (PCBP1 and PCBP2) and is oxidized by ferroxidase activity of HFT in an oxygen-dependent manner. Then $\mathrm{Fe}^{3+}$ is stored in the cavity formed by LFT. Iron is released from FT in a controlled manner by autophagy involving a cargo receptor, the nuclear receptor coactivator 4 (NCOA4).

The only known mammalian iron exporter is ferroportin (FPN), a transmembrane protein which requires a multicopper ferroxidase to convert $\mathrm{Fe}^{2+}$ to $\mathrm{Fe}^{3+}$, allowing binding to TF. Hephaestin (HEPC), ceruloplasmin (CP), amyloid-beta precursor protein (APP), and the newly identified zyloklopen (ZP) are co-localized with FPN at the surface membrane or secreted. 


\subsubsection{Iron Flux in Retina}

A local retinal homeostasis of iron, independent from the systemic regulation, is suspected by the fact that main proteins involved in iron homeostasis, previously confined to systemic expression, are locally synthesized in the retina (Table 1). In addition, the outer and inner BRB prevents the entry of large quantities of iron into the eye in case of systemic iron overload. The study of mouse models invalidated for iron homeostasis proteins (Table 1) led to a hypothetical model in which iron entry and homeostasis in the retina is divided into two compartments, carried by the RPE and MGC, delimited by the external limiting membrane, and having limited exchanges in physiological condition. 
Table 1. Proteins involved in iron homeostasis of the retina.

\begin{tabular}{|c|c|c|c|c|c|}
\hline & Proteins & Expression & Functions & Knock-Out Rodent Models & Human Pathologies \\
\hline \multirow{14}{*}{ Iron uptake/export } & Transferrin (TF) & RPE, PR, MGC [8] & $\begin{array}{l}\text { Extracellular transporter binding two } \\
\text { ferric iron ions }\left(\mathrm{Fe}^{3+}\right)[\text { holoTF]. Kd }= \\
\qquad 10^{22} \mathrm{M}^{-1}\end{array}$ & $\begin{array}{l}H p x^{-l-} \text { : Decrease of the electroretinogram. Decrease } \\
\text { TF, CP, TFR1 [17] }\end{array}$ & Congenital atransferrinemia \\
\hline & Transferrin receptor 1 (TFR1) & $\begin{array}{l}\text { RPE, IS, OPL, INL, GCL, } \\
\text { endothelial cells [8] }\end{array}$ & Transmembrane receptor of holoTF & ND & ND \\
\hline & Lactoferrin (LF) & RPE [18] & $\begin{array}{l}\text { Extracellular transporter binding two } \\
\qquad \mathrm{Fe}^{3+}\end{array}$ & $\begin{array}{l}\mathrm{Lf}^{-/-}: \text {Higher susceptibility for laser induced } \\
\text { choroidal neovascularization [19] }\end{array}$ & ND \\
\hline & $\begin{array}{c}\text { Lipocalin } 2(\mathrm{LCN} 2) \text { or } \\
\text { (neutrophil } \\
\text { gelatinase-associated lipocalin } \\
\text { (NGAL) or 24p3 } \\
\end{array}$ & $\begin{array}{l}\text { RPE, MGC, neural retina, } \\
\text { microglia [20] }\end{array}$ & $\begin{array}{c}\text { Extracellular transporter which binds } \\
\mathrm{Fe}^{+3} \text { by sequestering bacterial and } \\
\text { mammalian siderophores } \\
\text { (2,5-dihydroxybenzoic acid). }\end{array}$ & $\begin{array}{l}L c n 2^{-l-}: \text { Expression of LFT, TF et TFR1 unchanged } \\
\text { (personal data) }\end{array}$ & ND \\
\hline & $\begin{array}{l}\text { 24p3R or (the solute carrier } \\
\text { family } 22 \text { member } 17 \\
\text { (SLC22A17) }\end{array}$ & RPE [21] & $\begin{array}{l}\text { Transmembrane receptor of LCN2 under } \\
\text { holo- and apo-forms }\end{array}$ & & \\
\hline & $\begin{array}{l}\text { Megalin or (low density } \\
\text { lipoprotein receptor-related } \\
\text { protein 2 (LRP2) }\end{array}$ & RPE [22] & $\begin{array}{c}\text { Transmembrane multiligands receptor } \\
\text { (such lipocalin 2, lactoferrin, transferrin), } \\
\text { co-receptor Cubulin }\end{array}$ & $\begin{array}{c}\operatorname{Lrp2}^{F / F} \text { (FoxG1 }{ }^{\mathrm{Cre}+} \text { ): myopia, hypertrophic RPE and } \\
\text { retinal degeneration [22]. Increase FT and decrease } \\
\text { TFR1 (personal data) } \\
\end{array}$ & $\begin{array}{l}\text { Donnai-Barrow syndrome: high } \\
\text { myopia, retinal detachment }\end{array}$ \\
\hline & Ferroportin (FPN) or (SLC40A1) & $\begin{array}{l}\text { RPE, IS, OPL, IPL, MGC, REC } \\
{[23]}\end{array}$ & $\begin{array}{l}\text { Transmembrane transporter which } \\
\text { exports ferrous iron }\left(\mathrm{Fe}^{2+}\right) \text { outside the } \\
\text { cell in cooperation with ferroxidases }\end{array}$ & $\begin{aligned} F p n^{\mathrm{C} 326 \mathrm{~S}} \text { : HEPC-resistant FPN mice. Increase FT, iron } \\
\text { deposits in RPE and choroid [24] }\end{aligned}$ & Hemochromatosis type 4 \\
\hline & Ceruloplasmin $(\mathrm{CP})$ & RPE, MGC [25] & $\begin{array}{l}\text { Extracellular ferroxidase that oxidizes } \\
\mathrm{Fe}^{2+} \text { in } \mathrm{Fe}^{3+} \text {. Exists a } \\
\text { glycosylphosphatidylinositol-anchored } \\
\text { form } \\
\end{array}$ & \multirow{2}{*}{ 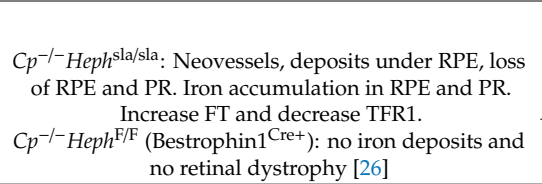 } & $\begin{array}{l}\text { Aceruloplasminemia: iron deposits } \\
\text { in drusen and RPE. Dry-AMD like } \\
\text { phenotype [27] }\end{array}$ \\
\hline & Hephaestin (HEPH) & RPE, PR, MGC [25] & $\begin{array}{l}\text { Extracellular ferroxidase. } 50 \% \text { of } \\
\text { homology with CP }\end{array}$ & & ND \\
\hline & $\begin{array}{l}\text { Amyloid-beta precursor protein } \\
\text { (APP) }\end{array}$ & RPE, IS and OS, MGC, GCL [26] & Membrane ferroxidase & $\begin{array}{l}A p p^{-I-}: \text { Disturbances of synaptic development of } \\
\text { secondary neurons [28]. }\end{array}$ & $\begin{array}{l}\text { Associated with Alzheimer disease } \\
\text { and cerebral amyloid angiopathy }\end{array}$ \\
\hline & Zyklopen (ZP) & RPE, GCL $[26,29]$ & Membrane ferroxidase & ND & ND \\
\hline & $\begin{array}{l}\text { DMT1 (Divalent Metal } \\
\text { Transporter 1) or Natural } \\
\text { resistance-associated } \\
\text { macrophage protein (NRAM2) } \\
\text { or SLC11A2 }\end{array}$ & $\begin{array}{l}\text { IS, horizontal and rod bipolar } \\
\text { cells }[30]\end{array}$ & $\begin{array}{l}\text { Transmembrane import of } \mathrm{Fe}^{2} \\
\text { Iron exit from endosomal vesicle or } \\
\text { cytosol under acidic } \mathrm{pH}(5.5) \text {. }\end{array}$ & ND & $\begin{array}{l}\text { Microcytic hypochromic anemia } \\
\text { with iron overload }\end{array}$ \\
\hline & $\begin{array}{l}\text { ZIP14 (Zinc transporter 14) or } \\
\text { SLC39A14 }\end{array}$ & \multirow[t]{2}{*}{$\begin{array}{l}\text { CEC, RPE, PR, MGC, GCL, REC } \\
{[31]}\end{array}$} & \multirow{2}{*}{$\begin{array}{l}\text { Transmembrane zinc transporter which } \\
\text { uptakes unbound } \mathrm{Fe}^{2+} \text { in cytosol. } \\
\text { Optimal at physiological } \mathrm{pH}(7.4)\end{array}$} & \multirow[t]{2}{*}{$\mathrm{ND}$} & $\begin{array}{c}\text { Hypermanganesemia with } \\
\text { dystonia 2; Hyperostosis cranialis } \\
\text { interna. }\end{array}$ \\
\hline & $\begin{array}{l}\text { ZIP8 (Zinc transporter 8) or } \\
\text { SLC39A8 }\end{array}$ & & & & $\begin{array}{l}\text { Congenital disorder of } \\
\text { glycosylation } 2 \mathrm{~N}\end{array}$ \\
\hline
\end{tabular}


Table 1. Cont.

\begin{tabular}{|c|c|c|c|c|c|}
\hline & Proteins & Expression & Functions & Knock-Out Rodent Models & Human Pathologies \\
\hline \multirow[t]{7}{*}{ Storage } & Ferritin (FT) & $\begin{array}{l}\text { Ubiquitous and highly express } \\
\text { in RPE, SS, bipolar cells [8] }\end{array}$ & $\begin{array}{l}\text { Cytosolic complex of } 24 \text { subunits of heavy }(\mathrm{H}) \text { and light }(\mathrm{L}) \text { chains, } \\
\text { which can store } 4,500 \mathrm{Fe}^{3+} \text {. The H subunits have ferroxidase activity. } \\
\text { FT has also a nuclear localization }\end{array}$ & $\mathrm{Hft}^{++-}:$Higher sensibility for stress [32] & $\begin{array}{l}\text { HFF: Hemochromatosis type 5LFT: } \\
\text { Hyperferritinemia with or without } \\
\text { cataract; Neurofertininoathy; } \\
\text { L-ferritin deficieincy. }\end{array}$ \\
\hline & Mitochondrial ferritin (FtMt) & $\begin{array}{l}\text { All retina layers, with higher } \\
\text { expression in RPE and } \\
\text { ellipsoids of IS [30] }\end{array}$ & $\begin{array}{l}\text { Mitochondria iron transporter. Share } 79 \% \text { of homology with HFT and } \\
\text { has ferroxidase activity }\end{array}$ & ND & $\mathrm{ND}$ \\
\hline & Transferrin receptor 2 (TFR2) & RPE, IS, OPL, IPL [33] & $\begin{array}{l}\text { Transmembrane receptor of holo-TF which regulates transcription of } \\
\text { HEPC in cooperation with HFE under TF iron-saturation }\end{array}$ & ND & Hemochromatosis type 3 \\
\hline & $\begin{array}{l}\text { Hereditary hemochromatosis protein } \\
\text { (HFE) }\end{array}$ & $\operatorname{RPE}[33]$ & $\begin{array}{l}\text { Membrane protein which bind } \beta 2 \mathrm{M} \text { to TFR1 or TFR2 in function of TF } \\
\text { iron-saturation }\end{array}$ & $\begin{aligned} H f^{-1-}: & \text { Hypertrophy/Hyperplasia of RPE, PR } \\
& \text { degeneration. Increase FT [34] }\end{aligned}$ & $\begin{array}{c}\text { Hemochromatosis type 1: } \\
\text { Dysmorphism of RPE, drusen and } \\
\text { alteration of vision [30]. Variegate } \\
\text { porphyria. Microvascular } \\
\text { complications of diabetes } 7\end{array}$ \\
\hline & $\beta$-2-Microglobulin ( $\beta 2 \mathrm{M}$ ) & RPE, OS, IS, OPL, INL, IPL [33] & Membrane protein involved in HFE-TFR1/2 interaction & ND & Immunodeficiency 43; Amyloidosis 8. \\
\hline & Bone Morphogenetic protein 6 (BMP6) & RPE, IS, OPL, IPL, GCL & $\begin{array}{l}\text { Extracellular protein which regulates HEPC transcription. Bind } \\
\text { Activin A receptor (AccriA) and BMP receptor type II (BMPR2) and } \\
\text { HJV as coreceptor, all expressed in retina }\end{array}$ & $\begin{array}{l}\text { Bmp } 6^{-1} \text { : Iron accumulation in RPE and retina. RPE } \\
\text { hypertrophy and PR degeneration. Decrease TFR1 } \\
\text { and increase LFT [35] }\end{array}$ & ND \\
\hline & Hemojuvelin (HJV) & RPE, PR, MGC, GCL [36] & Regulation of HEPC transcription & $\begin{array}{c}\mathrm{Hj}^{-{ }^{-}}: \text {: Neovessels in retina, gliosis, inner BRB } \\
\text { leakage, PR degeneration. Increase LFT [37] }\end{array}$ & Hemochromatosis type $2 \mathrm{~A}$ \\
\hline \multirow[t]{3}{*}{ Regulation } & $\begin{array}{c}\text { Transmembrane serine protease } 6 . \\
\text { (TMPRSS6) or Serine protease } \\
\text { matriptase-2 }\end{array}$ & RPE, MGC GCL [38] & Membrane protein with serine protease activity which cleave HVJ & 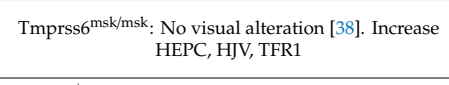 & Iron-refractory iron deficiency anemia \\
\hline & Hepcidin (HEPC) & RPE, IS, MGC, OPL [36] & $\begin{array}{l}\text { Peptide hormone which transcription is activated by TF saturation or } \\
\text { inflammation. Induces the degradation of FPN reducing iron export }\end{array}$ & $\begin{array}{l}\text { Hamp }^{-/ \text {: }} \text { Iron accumulation in RPE/choroid and in } \\
\text { retina. Decrease TFR1 and increase FPN [39] }\end{array}$ & Hemochromatosis type $2 B$ and juvenile \\
\hline & $\begin{array}{l}\text { Iron regulatory protein (IRP1) or } \\
\text { cytoplasmic aconitase hydratase (ACO1) }\end{array}$ & Ubiquitous & $\begin{array}{l}\text { Iron sensor protein with cluster iron-sulfur. Bind Iron responsive } \\
\text { element (IIRE) in targetet mRNA when intracellular iron levels are low. } \\
\text { Under high iron condition, IRP1 is converted into an aconitase whereas } \\
\text { IRP2 is degraded in proteasome }\end{array}$ & $\begin{array}{l}\text { Ireb1 } 1^{+/-} \text {Ireb2 } 2^{-/} \text {: No retinal alteration. Increase FPN } \\
\text { and LFT [30] }\end{array}$ & ND \\
\hline
\end{tabular}

Hypoxia Inducible Factor (HIF) $\quad$ RPE, PR ONL, INL, GCL [40,41] $\begin{gathered}\text { Transcriptional regulator. Oxygen sensor sensitive to iron level. } \\ \text { Bind Hypoxia responsive element (HRE) in target mRNA under }\end{gathered}$

ND

Familial erythrocytosis (HIF2 $\alpha)$

Legend Table 1: Proteins localization were obtained from immunostaining on sections of mouse/rat retinas. The mouse models presented are limited to those with retinal changes in iron homeostasis and retinal abnormalities, if any. The corresponding human diseases were obtained by searching the UniProt site. ND: Not determined. Legends: $\beta 2 \mathrm{M}$ : $\beta$-2-Microglobulin; CP: ceruloplasmin; CEC: choroidal endothelial cell; FT: ferritin; GCL: ganglion cells layer; HFE: hereditary hemochromatosis protein, HFT: ferritin heavy chain; IPL: inner plexiform layer; IRE: iron responsive element; IS: inner segments; LFT: ferritin light chain; MGC: Müller's glial cell; OPL: outer plexiform layer; OS: outer segments; PR: photoreceptor; REC: retinal endothelial cell; RPE: retinal pigment epithelium; TFR1: transferrin receptor 1. 
Transferrin-Bound Iron Transport in the Retina

The RPE imports iron bound to TF from the choriocapillaries through the transcytosis of TFR1 present at the basal membrane of the RPE (Figure 2). The transcytosis of the TF/TFR1 complex along microtubules via galectin 4 and Rab11a [42] has been described in vitro. The presence of TFR1 on the apical side of RPE is ambiguous and suggests that TF/TFR1 transcytosis or a potential iron-TF uptake by RPE could egress iron from the outer retina to choriocapillaries. Six hours after an intravitreal injection of holoTF tagged with a fluorochrome, TF is localized in RPE and choroid, which favors the later hypothesis [43]. Another iron entry in RPE is the phagocytosis of PR outer segments which contains high quantities of iron [8]. Once in RPE cytosol, iron is stored in FT and in melanosomes [44]. The release of iron from cell is possible through FPN present at the basal membrane of RPE and a multicopper ferroxidase. HEPH, CP, and APP but not ZP are expressed in RPE [26].

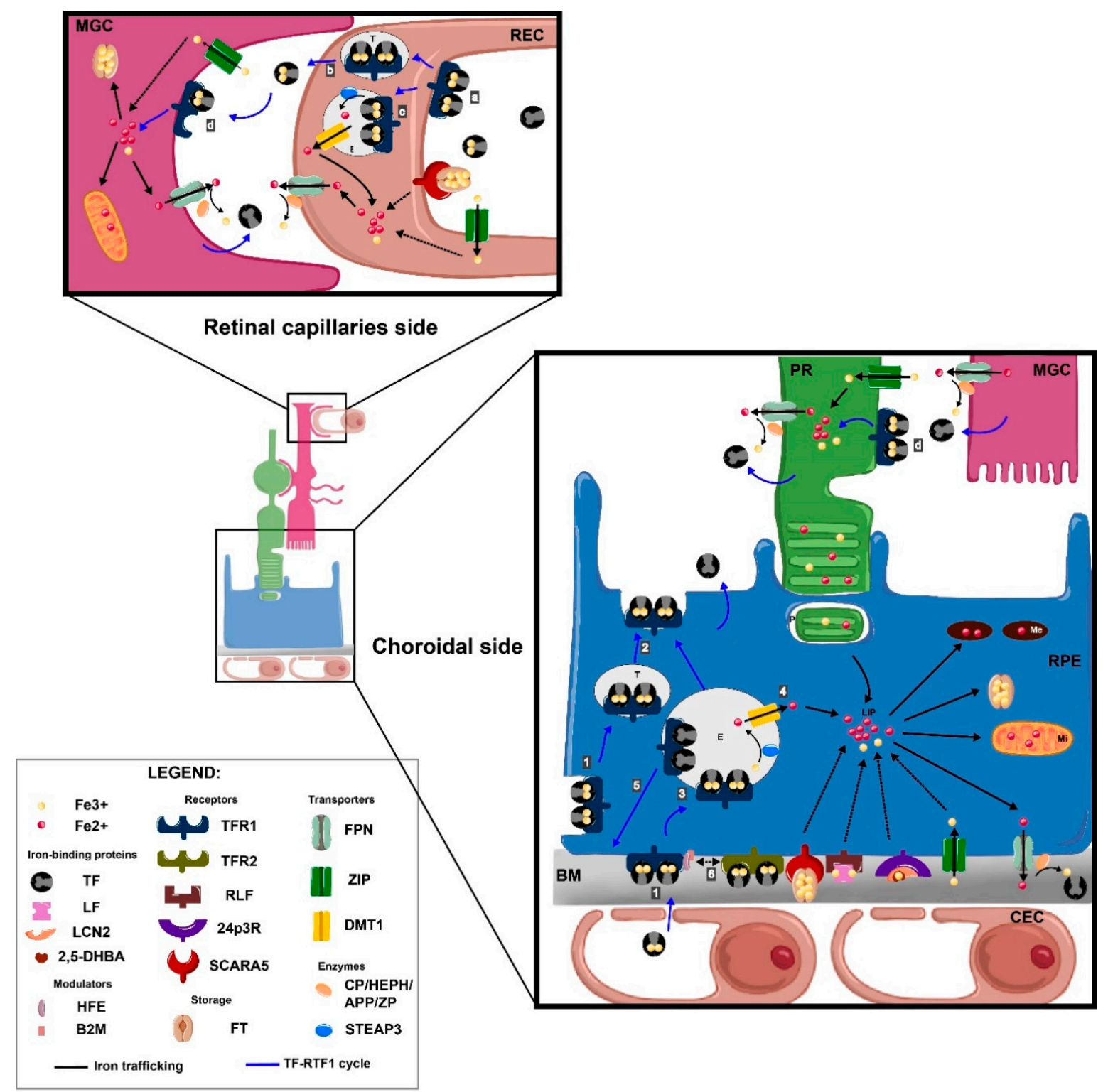

Figure 2. Iron uptake from capillaries and transport in the retina. Legend Figure 2: Under physiological condition, non-heme iron $\left(\mathrm{Fe}^{3+}\right)$ in the circulation is transported bound to transferrin (TF). 
A. At the choroidal side, $\mathrm{Fe}^{3+}$ linked to TF is captured by its receptor 1 (TFR1) (1) at the basolateral level of the retinal pigment epithelium (RPE) (blue arrows). The internalized TF/TFR complex is transported to the apical pole by transcytosis (T) (2) or to the endosome (E) (3). In this case, $\mathrm{Fe}^{3+}$ is released from TF and reduced by the metaloreductase six transmembrane epithelial antigen of the prostate 3 (STEAP3) to ferrous iron $\left(\mathrm{Fe}^{2+}\right)$ and then exported to the cytosol by the transporter divalent metal transporter 1 (DMT1) where it constitutes the free iron pool (LIP) (4). TF and TRF1 are recycled to membrane (5). Iron is then transported from LIP to the organelles as needed, either stored in ferritin (FT) and melanosomes (Me), or exported by ferroportin (FPN) coupled to ferroxidases such as ceruloplasmin $(\mathrm{CP})$ or hephaestin (HEPH), amyloid-beta precursor protein (APP) or zyloklopen (ZP) (black arrows). Hemochromatosis protein (HFE) and beta-2 microglobulin (B2M) associated to TFR1, shift to TFR2 in case of iron overload (saturation of TF) and activate hepcidin (HEPC) transcription (6). B. At retinal capillaries side, $\mathrm{Fe}^{3+}$ bound to TF is up-taken by TFR1 at the luminal side of retinal endothelial cells (REC) (a), and TF/TFR1 pass directly through transcytosis into the retina (b) or endocytosed then exported by FPN (c). TF synthetized by RPE, Müller glial cells (MGC) or photoreceptors (PR) up-taken retinal iron (d) and distributed it throughout the retina, especially to PR. Phototransduction performed on the outer segments of PR is a highly iron-dependent process. PR uptake $\mathrm{Fe}^{3+}$ bound to TF by TFR1 presents in inner segments and export it by FPN or by phagocytosis $(\mathrm{P})$ of the outer segments of PR by RPE. TF-independent iron delivery to the retina can occur, especially in case of systemic iron dysregulation (black dotted lines). Serum FT has a specific receptor, the scavenger receptor class A, member 5 (SCARA5) localizes at the basal membrane of RPE, luminal side of REC, PR and MGC. Lactoferrin (LF), a member of TF superfamily and its receptors (LFR) are present in RPE. Fe ${ }^{3+}$ captured by a siderophore (2,5-dihydroxybenzoic acid (2,5-DHBA)) is bound by lipocalin 2 (LCN2) and its receptors (24p3R) in RPE. The non-TF-bound iron (NTBI) is up-taken by MGC, REC, PR and RPE by DMT1 or ZRT/IRT-like proteins (ZIP) importers. BM: Bruch's membrane; CEC: choroidal endothelial cell; E: endosome; Me: melanosome; MGC: Müller's glial cell; MI: mitochondria; P: phagosome; PR: photoreceptor; REC: retinal endothelial cell; RPE: retinal pigment epithelium; T: transcytosis.

In the inner retinal layers, iron is imported through retinal endothelial cells (REC) which express TFR1 at their luminal side [45]. Two mechanisms of iron transfer across the abluminal membrane of REC into the retina are evoked: TF/TFR1 transcytosis or/and TF/TFR1 endocytosis following by iron released from endosome and iron export by FPN. The abluminal membrane of REC expresses FPN colocalized with HEPC, CP, and APP [24,31]. Iron is bound by TF and distributed to the retina or the vitreous. With its unique position extending from the vitreous to PRs and its capacity to synthetize TF [46] and to express FPN [24], MGC plays a crucial role in the distribution of iron from the inner retina to the inner segment of the PR.

Iron presents in the non-vascularized subretinal space, between the apical side of RPE and the PR, is mainly bound to TF, secreted by PRs and RPE, and up-taken by PRs for their highly metabolism activities, by TFR1 express at inner segments. The PR inner segment is the iron storage compartment for PR segments, where both FT chains and mitochondrial FT are highly concentrated [30]. Iron export from the PR is ensured mostly by FPN also present in inner segments, CP and HEPH being poorly involved in favor of APP [26].

\section{Non-Transferrin-Bound Iron Transport in the Retina}

Whereas iron-bound TF is the main transport system to cross the BRB, transferrin-independent iron delivery to the retina can occur (Figure 1). Serum FT, exclusively composed of LFT has specific receptor, the scavenger receptor class A, member 5 (SCARA5) expressed in cytoplasm and nucleus in retinal endothelial cells, ganglion cells, astrocytes, the inner nuclear layer, MGC, microglia, outer nuclear layer, cones segments and RPE. After intravenous injection, serum FT remained confined in retinal endothelial cells in the inner retina [47]. Another protein possibly involved in iron transport is lactoferrin (LF), a multifunctional protein which shares $65 \%$ of homology with TF. It is synthesized in various human ocular tissues mainly in the RPE but not in the neural retina [18]. LF receptors have 
not been studied in the eye but are present in the brain [48]. Lipocalin 2 (LCN2) does not bind to iron directly, but through interaction with siderophores (catecholate and carboxylate) as cofactors [49] could also be implicated in iron transport in the retina [20]. $\beta$-hydroxybutyrate dehydrogenase-2 (Bdh2), an enzyme that is critical for the synthesis of 2,5-dihydroxybenzoic acid (2,5-DHBA), the mammalian siderophore, is found throughout the retina in all cell layers, including ganglion cells, MGC, and RPE cells [50]. Two major membrane-bound receptors for LCN2, megalin and 24p3R, have been identified in RPE [21,22]. Although LCN2 is being recognized as an important factor in retinal diseases [21], its exact contribution in iron retinal transport in health and diseases remain to be determined.

In case of iron overload, the NTBI could be up taken by iron importer ZIP or DMT1. This could explain why in retinal iron overload models, iron continues to accumulate despite the reduced expression of TFR1 in retina and RPE [31]. The specific localization of DMT1 in PRs and bipolar and horizontal cells suggests that it could be involved in providing iron to these cells, for phototransduction or neurotransmitter synthesis [30] ZIP8 and ZIP14 are expressed in RPE, choroid, REC, choroidal endothelial cells (CEC), ganglion cells, PRs, and MGC. At a high degree of TF saturation in the retina, there is a decreased ZIP14 expression whereas ZIP8 expression remains stable [31].

\subsubsection{Iron Regulation in Retina}

Cellular iron uptake and release and the intracellular LIP size are tightly controlled. Transcriptional, post-transcriptional, and post-translational processes regulate iron homeostatic proteins (for a review, see [51]). The main mechanisms of intra- and extra-cellular regulation of iron levels are limited to two extremely controlled systems.

The first system includes iron regulatory proteins (IRP) 1 and 2-intracellular iron regulatory proteins which, depending on the amount of iron, bind iron responsive element (IRE) sequences present on the mRNAs of iron homeostasis proteins such as FPN, TFR1, FT, and DMT1. Depending on the position of the IRE site, IRP controls their translation or degradation. Under conditions of increased cellular iron, IRP1 loses its IRE-binding activity by acquiring an iron in the $4 \mathrm{Fe}-4 \mathrm{~S}$ cluster, whereas IRP2, is degraded by proteasome. In this condition, $t f r 1$ and $d m t 1 \mathrm{mRNA}$ are degraded, whereas $f t, f p n$, and hif- $2 \alpha$ mRNA are translated. The localization of IRP1 and IRP2 has not yet been identified in the retina but their expressions are ubiquitous in mammalian cells. Mice with $\operatorname{Irp} 1^{+/-} \operatorname{Irp} 2^{-/-}$genotype show more severe neurodegenerative disease than Irp2 $2^{-/}$animals [30]. These IRP deficient retinas have increased FPN and FT in the inner segments, MGC endfeet, and inner retina compared to age and strain matched wild type retinas, suggesting that FPN and FT levels are regulated by IRPs in the retina [23]. In a model of light induced retinal degeneration, $2 \mathrm{~h}$ after light exposure, Irp 2 but not Irp1 mRNA increased in the retina [32].

The second system focuses on hepcidin (HEPC), a peptide hormone principally synthetized by the liver. However, HEPC is also synthesized by PR, RPE, and MGC [39]. It is activated by two cellular signaling pathways induced by excess of iron, the transferrin receptor 2 (TFR2)/Human homeostatic iron regulator protein (HFE) pathway and the Bone Morphogenetic protein (BMP6)/Mothers against decapentaplegic homolog 1 (SMAD) pathway. When the TF saturation is high at the basolateral level of the RPE, the HFE is released from TFR1 and binds to TFR2, which activates the transcription of HEPC. BMP6 secreted by the retina and the RPE, binds to its receptors coupled to hemojuvelin (HJV) protein at the apical level of RPE in order to activate the synthesis of HEPC [35]. HEPC binds to the extracellular domain of FPN on the cell surface, leading to its internalization and degradation, effectively preventing cellular iron export and limiting the amount of iron that gets into the extracellular fluid. The specific deletion of HEPC in the retina does not lead to age-associated retinal iron accumulation, whereas liver-specific HEPC silencing leads to early serum, RPE, and retina iron accumulation followed by retinal degeneration [52].

Finally, the hypoxia inducible factor (HIF) acts as a transcription factor for certain iron homeostasis genes such as the $T f, t f r 1, D m t 1, F p n$, and $C p$ genes by binding to a specific hypoxia-responsive element (HRE) site present on their mRNAs. Expression and degradation of HIF are also dependent on iron. In 
fact, $\mathrm{Fe}^{2+}$ is the cofactor of prolyl hydroxylase involved in the degradation of HIF- $1 \alpha$, and at the same time HIF- $2 \alpha$ has an IRE sequence in the $5^{\prime}$ UTR of its mRNA, which in the condition of iron deficiency, inhibits its translation. Nuclear staining of HIF- $1 \alpha$ was observed in the GCL, the inner nuclear layer and the outer nuclear layer in human and rat [41]. Under retinal hypoxia, both HIF- $1 \alpha$ and HIF-2 $\alpha$ are activated but have cell specific expression within the inner retina. Specifically HIF- $2 \alpha$ activation seems to play a key role in regulating the response of MGC to hypoxia [53].

\section{Physiopathological Role of Iron in the Retina}

\subsection{Iron in Cellular Metabolism/Functions}

\subsubsection{Iron as a Fe-S Structural Motif Involved in Various Cellular Machinery Proteins}

Iron sulfur (Fe-S) proteins are characterized by the presence of Fe-S clusters localized in different cell compartments (for review [54]). IRP1 is a Fe-S cluster that participates in sensing and regulating iron homeostasis in the retina. Frataxin is a nuclear-encoded mitochondrial protein involved in Fe-S cluster assembly, heme synthesis, and intracellular iron homeostasis. Frataxin is an allosteric activator which binds to this assembly complex [55]. It is present in the retina [56] and in the RPE [57] and could be responsible for retinal neurodegeneration induced by defective mitochondrial function [58]. In addition, Fe-S clusters may act as biological sensors by their binding properties to molecular oxygen and nitric oxide [59] both critical for the retinal physiology and pathology.

\subsubsection{Iron in Nucleic Acids Machinery, Cell Proliferation, and DNA Repair}

A recent review has reported the multiple implications of iron in DNA synthesis and repair, as well as in RNA metabolism [60]. Cytosolic and nuclear Fe-S proteins intervene in the genome stability [61]. Iron has been implicated in DNA synthesis and repair as a cofactor of sirtuin 2, an histone deacetylase, involved in iron homeostasis [62]. Sirtuin 2 maintains cellular iron levels by binding the nuclear factor erythroid-2-related factor 2 (NRF2) leading to a reduction in total and nuclear NRF2 levels. NRF2 is a transcription factor that plays key roles in retinal antioxidant and detoxification responses and has been linked with the development of age-related macular degeneration (AMD) [63].

Mitochondria are a major source of ROS and mitochondrial DNA is very susceptible to oxidative damage [64]. In RPE cells, mitochondrial DNA is damaged by hydrogen peroxide [65]. Deletions in mitochondrial DNA occurred in function of age in human neural retina [66], and the accumulation of age-related mitochondrial mutations in the eye has been correlated with a decrease in ATP production and increase ROS output, leading to oxidative stress, inflammation, and degradation [67].

\subsubsection{Iron in Oxygen Transport and Regulation}

Hemoglobin is synthetized in the retina [68]. It is one of the main protein synthesized in primary cultures of human RPE and secreted in vivo through the basolateral membrane [69].

Under physiological condition, free hemoglobin is bound by haptoglobin, but in case of massive hemolysis, hemoglobin releases free heme which binds hemopexin. Both hemopexin and haptoglobin have been described in the human retina [70,71]. The mRNAs for both haptoglobin and hemopexin were detected in the neural retina and PR as well as ganglion cells but not in RPE cells.

Neuroglobin is a highly conserved oxygen-binding protein reviewed in [72] and highly expressed in the retina. Its role is to facilitate oxygen metabolism, being localized in mitochondria. Hemin, the ferric chloride salt of heme enhances neuroglobin expression and protects animal model of $\mathrm{N}$-methyl-N-nitrosourea-induced retinal degeneration [73]. In this model, hemin protects also cones from apoptosis. Neuroglobin has also been associated with retinal damage induced by light [74] which may reflect the changes in iron metabolism first described with light on retina [32]. It has also been associated with VEGF expression and thus could participate in retinal angiogenesis [75]. 
Heme, $\mathrm{Fe}^{2+}$ protoporphyrin IX, the prosthetic group of hemoproteins including hemoglobin, neuroglobin, oxidases/peroxidases, or cytochromes can be released after auto-oxidation. Heme transporter proteins also intervene in iron metabolism in the retina, and their dysregulation could potentially cause oxidative cell damage. All three heme transporters feline leukemia virus subgroup $C$ receptor (FLVCR), breast cancer resistance protein (BCRP), and proton-coupled folate transporter (PCFT/HCP-1) are expressed in the retina and RPE. In the RPE, the expression of FLVCR is restricted to the apical membrane and the expression of BCRP and PCFT to the basolateral membrane. In cases of iron overload, the expression of FLVCR and PCFT is upregulated and BCRP is downregulated, suggesting an important role of heme transporter proteins in retinal iron regulation [76].

\subsubsection{Iron and Visual Function}

The involvement of iron in the vision cycle was discovered with the characterization of the enzyme RPE65, as an iron-dependent isomerohydrolase [77]. RPE65, abundant in the RPE [78], ensures the isomerization and hydrolysis of all-trans retinyl ester to 11-cis retinol. RPE65 is essential for vision, and mutations in rpe65 genes induce Leber congenital amaurosis, a form of retinitis pigmentosa that leads to blindness [79]. Recently, RPE65 was also shown to intervene in the production of meso-zeaxantin, an ocular specific carotenoid which protects the fovea from oxidative stress [80].

An alternate pathway for 11-cis retinol recycling has been described in MGC by isomerases 1 or 2 that also appear to be iron dependent [81]. Few studies have analyzed the iron flux in the retina with the diurnal cycle conversely to what has been performed in brain in mice [82,83]. Among the sensory guanylate cyclase proteins and signaling network, guanylyl cyclase activating protein 5 is the only protein that binds strongly $\mathrm{Fe}^{2+}$ in zebrafish [84]. It is proposed as redox sensor in visual transduction.

Phototransduction depends on the phagocytosis of outer segments from PR by the RPE. The constant release of the outer segments from PR and their digestion during phagocytosis by RPE implies membrane biogenesis, a process which needs iron as a cofactor of fatty acid desaturase [85]. Royal College Surgeon (RCS) rats invalided for the phagocytosis protein Myeloid-epithelial-reproductive tyrosine kinase (MERTK) have increased iron in retina and particularly in RPE phagosomes and also increased retinal FT and TF expression [86].

Iron is also involved in neurotransmitters secretion as it regulates glutamate secretion by RPE cells via the cytosolic aconitase pathway [87]. Dopamine biosynthesis in specialized amacrine cells results from the conversion of the amino acid L-tyrosine in L-3,4-dihydroxyphenylalanine (L-DOPA) using oxygen and $\mathrm{Fe}^{2+}$ [88]. Synaptosomal nerve-associated protein 25 (SNAP-25) is a Fe-S protein involved in synapse vesicle fusion with plasma membranes highly present in retina [89].

A significant number of ATP binding cassette $(\mathrm{ABC})$ transporters, involved in lipid trafficking in retinal cells, have been linked to severe genetic ocular diseases [90]. ABCA4 is present in the PR and transports 11-cis and all-trans isomers of $\mathrm{N}$-retinylidene-phosphatidylethanolamine across disc membranes, preventing the accumulation of toxic bisretinoid lipofuscin compounds in PR and RPE cells. In Abca4 null mutant mouse which presents accumulation of $\mathrm{N}$-retinylidineN-ethanolamine (A2E) bisretinoids and lipofuscin in the RPE, intracellular iron accumulation is also observed which contributes to enhancing oxidative cell death [91]. The intracellular accumulation of iron in cells of the $\mathrm{RPE}$ in culture decreases the expression of the transporters of cholesterol ABCA1/ABCG1, increasing the level of pro-inflammatory cholesterol in retina [50].

\subsection{The Dark Side of Iron}

\subsubsection{The Crucial Role of Iron in Oxidative Stress-Mediated Damages in the Retina}

The ability of iron to change easily its valence and switch between the $\mathrm{Fe}^{2+}$ and $\mathrm{Fe}^{3+}$ forms, providing or accepting electrons, respectively, ensures a privileged position in living matter as mediator of key biochemical reactions. However, the presence of free labile iron in cell or NTBI in circulation is prone to generate highly ROS in the Fenton/Haber-Weiss reaction. 
$\mathrm{Fe}^{2+}+\mathrm{H}_{2} \mathrm{O}_{2} \rightarrow \mathrm{Fe}^{3+}+\mathrm{OH}^{-}+\mathrm{HO}:$ Fenton reaction

$\mathrm{O}_{2}{ }^{--}+\mathrm{Fe}^{3+} \rightarrow \mathrm{O}_{2}+\mathrm{Fe}^{2+}$ : Haber-Weiss reaction

$\mathrm{O}_{2}^{--}+\mathrm{H}_{2} \mathrm{O}_{2} \stackrel{\mathrm{Fe}^{2+} \stackrel{\mathrm{Fe}^{3+}}{\rightarrow}}{\mathrm{O}} \mathrm{O}_{2}+\mathrm{OH}^{-}+\mathrm{HO}:$ Fenton/Haber-Weiss reaction

The toxicity of free iron has been extensively studied on neuronal and retinal cells, and they are not sensitive to the same doses of iron [46,92,93], the cones being the most sensitive to iron [94]. In RPE cells, the interaction of iron with bisretinoids and lipofuscin induces cell damage and retinal degeneration [91]. Conversely, melanin can bind large amounts of iron to preserve the RPE and the choroid from a pro-oxidant environment, intensified by light exposure. However, with age, the accumulation of iron in melanosomes associated with a reduction in the amount of melanin in RPE promotes the formation of free radicals [95]. Exposure of RPE cells to high non-lethal doses of iron leads to a decrease in phagocytic and lysosomal activity [15], favoring the accumulation of breakdown products of Vitamin A (lipofuscin) leading to the formation of glycation end products (AGE) present in drusen, RPE, and Bruch's membrane of AMD patients [91]. In addition, phagocytosis of PR discs, peroxidized by ferrous ions, damage the membranes of phagosomes and lysosomes in RPE cells in culture $[15,96]$.

In hypoxic conditions, an efflux of iron from RPE to the basolateral direction [97] could explain, at least in part, that PRs tolerate better hypoxia than hyperoxia [98]. $\mathrm{Fe}^{2+}$ contributes also to light-induced PR cell death through the production of hydroxyl radicals [99]. The ascorbate- $\mathrm{Fe}^{2+}$ complex induce lipid peroxidation in rod outer segment membranes and subsequently damage proteins such as rhodopsin by carbonylation or loss of thiol groups [100]. Finally, free heme can be also a source of redox-active iron and therefore highly toxic for the retina and for RPE cells [101].

In optic neuropathy, such as glaucoma, several mechanisms involved in ganglion cell death seem to be enhanced by iron-dependent oxidative stress [102,103].

Iron is thus a key component of oxidative-induced damages in the retina and in the RPE and involved in major cell death mechanisms.

\subsubsection{Retinal Cells Death Mechanisms in Iron Overload}

Iron overload, induced experimentally by the implantation of iron particles in rat vitreous cavity caused apoptosis (TUNEL-positive nuclei) in the outer nuclear layer after only 2 days [104]. Rat retinal explant exposed to iron showed an early increase of necrotic markers, such as lactate deshydrogenase, receptor-interacting serine/threonine-protein (RIP) kinase, and incorporation of propidium iodide, even before intraretinal iron accumulation was detected. Using retinal organo-culture, it was observed that iron deposits in retinal explants induced a shift from necrosis to apoptosis with activation of caspase 3 and TUNEL-positive nuclei [105]. Increased intraocular iron levels following intravitreal $\mathrm{FeSO}_{4}$ injection caused oxidative damage of $\mathrm{PR}$, as shown by the increase of superoxide radicals; hydroxynonenal, a marker of lipid peroxidation; and increased expression of heme oxygenase 1 [94]. Retinal iron overload also activates the NOD-like receptor family, pyrin domain containing 3 (NLRP3) inflammasome signaling pathway. In fact, the expression levels of NLRP3, activated caspase-1, a downstream target of NLRP3, and interleukin (IL) 1ß were higher in the retinas of HFE KO mice, a model of genetic iron overload [106]. Ferroptosis, a newly characterized form of necrosis, is induced by the accumulation of iron in degenerative diseases and has been described in RPE cells in culture subjected to oxidative stress [107]. Glutathione depletion also induced ferroptosis, autophagy, and premature senescence in RPE cells [108].

\subsubsection{Inflammation}

The general implication of iron in inflammation has been recently reviewed, and it will not be detailed here [109]. In RPE cells, the intracellular accumulation of iron activated the NRLP3 inflammasome pathway via the repression of the degradation of aluRNA by double-stranded RNA-specific endoribonuclease (DICER1). This mechanism involved the sequestration of the cofactor 
PCBP2 [110] and has been advocated in AMD. It has been also reported that iron induces the synthesis of complement $\mathrm{C} 3$ by activation of the Extracellular signal-regulated kinases (ERK)/SMAD3/CCAAT Enhancer Binding Protein Delta (CEBPD) 48 pathway [111]. The complement factor C5 carries between 13 and 15 iron atoms necessary for its conversion into an active form $\mathrm{C} 5$ b by $\mathrm{C} 5$ convertase, a complex formed from the cleavage products of C3 [112], which shows the importance of iron in complement pathways activation, a recognized risk factor for AMD [113].

The prion protein $\left(\mathrm{PrP}^{\mathrm{C}}\right)$, the principal protein implicated in the pathogenesis of human and animal prion disorders, is also implied in retinal degeneration due to iron metabolism dysfunction. This neuronal protein is expressed in many tissues of the eye, such as the retina and the cornea trabeculum. $\mathrm{PrPC}^{\mathrm{C}}$ is also expressed on the basolateral membrane of RPE, where it facilitates uptake of iron from choriocapillaries to neuroretina by functioning as a ferrireductase partner for divalent metal transporters. PrP-scrapie $(\operatorname{PrP}(\mathrm{Sc}))$, a misfolded isoform of this $\mathrm{PrP}^{\mathrm{C}}$ accumulates in the neuroretina resulting in iron accumulation [114].

In the brain, IL6 produced by microglia in response to lipopolysaccharide, induced the production of HEPC by astrocytes [115]. HEPC prevented the iron overload-activated neuronal apoptosis [115]. LPS induced also an HFE-independent expression of HEPC in MGC and in the RPE, both in vitro and in vivo. The increase in HEPC levels in retinal cells, occurring with a decrease in FPN levels, led to oxidative stress and apoptosis within the retina in vivo [116]. On the other hand, in both in vitro and in vivo models of amyloid $\beta$-induced pathology, HEPC downregulates the inflammatory and pro-oxidant processes in astrocytes and microglia and protected neurons from cell death [117]. Microglia and MGC activation associated with reactive gliosis has been observed in HJV knockout mice ( $\mathrm{Hjv}^{-/-}$mice) with aging and subsequent retinal iron accumulation [37].

The role of LCN2 has been suspected in AMD where its expression is increased in aqueous humor and in the infiltrating cells present in the retina and choroid [118]. An age-related increase in LCN2 was described in RPE cells of Beta-crystallin A3 (Cryba1) conditional knockout mouse, a model of AMD associated with chronic inflammation response [49], but the exact implication of LCN2 in iron metabolism in these models remains to be studied.

\subsubsection{Angiogenesis}

Increased iron levels in the retina could also have a role in the development of new vessels by inhibiting the anti-angiogenic effect of cleaved high molecular weight kininogen (Hka) [119], promoting the expression of succinate receptor 1 (SUCNR1 or GPR91) [120] which stimulates production of pro-angiogenic factors VEGF and angiopoietin [121]. In $\mathrm{Hjv}^{-/-}$mice, that leads to abnormal retinal iron overload. Proliferation of new leaky blood vessels in the vitreous was associated with reactive gliosis involving MGC and microglia [37]. In addition to proliferation by migratory cells, intravitreal hemoglobin also stimulates a transient proliferation in cells of the RPE and possibly in some supportive cells of the neural retina, such as MGC and astrocytes [122]. Iron also plays a role in HIF transcriptional regulation of pro-angiogenic genes [51]

\section{Role of Iron in Retinal Diseases}

\subsection{Siderosis and Retinal Hemorrhages}

Eye siderosis is probably the first known manifestation of iron toxicity for the eye. The presence of a foreign body containing iron inside the eyeball leads to various clinical complications including heterochromia of the iris, mydriasis, cataract, and retinal and RPE atrophy. Electroretinography analysis shows a decrease in a and $\mathrm{b}$ wave amplitudes, due to the progressive degeneration of the cones and rods (for a review, see [123]). The increase in iron can be observed histologically as a granular structure with FT or hemosiderin into cells. The level of vitreous iron also increases [124].

Retinal hemorrhages are present in several retinal pathologies, such as exudative AMD, diabetic retinopathy, or myopic degeneration, and they are particularly deleterious for vision when located 
in the subretinal space. Vision loss is dependent on the size of the hemorrhage and the ability of the tissue to shed blood $[125,126]$. During sub-macular hemorrhage early PR damage has been reported within $24 \mathrm{~h}$ [127]. In rabbits, the injection of their own blood into the subretinal space leads to a progressive degeneration of the PRs from one day after injection until a total destruction at 7 days, with an accumulation of iron in the outer segments of PR and in RPE [128]. The increased release of iron from hemoglobin induces peroxidation of unsaturated phospholipids, which are extensively present in the retina and affects particularly retinal neurons compared to the retinal glial cells [129].

\subsection{Retinal Manifestations of Inherited Iron Disorders}

Iron can accumulate in the retina of patients with inherited diseases involving mutations in genes encoding proteins of iron homeostasis, which can cause an imbalance in the metabolism of retinal iron. The most common hereditary hemochromatosis is related to a mutation in the Hfe gene resulting in excessive absorption of iron by the intestine and its accumulation in the organs. Mutations in the Tfr2, Fpn, Hjv, and Hepc genes are also involved in the development of hemochromatosis. The clinical findings associated to the retinal iron accumulation in these patients, as well as the impact on visual function, are quite rarely reported due to the variability of penetrance and the existence of a treatment reducing systemic iron overload. However, iron deposits and other changes in the RPE as well as visual acuity loss have been already reported [130].

Aceruloplasminemia is an autosomal recessive disorder caused by mutations in the $\mathrm{Cp}$ gene, resulting in a defect in the export of iron from cells. The retina, brain, and pancreas are overloaded with iron, leading to the clinical consequences as retinal degeneration, dementia, and diabetes. Several cases associating yellow discoloration of the fundus, atrophy of the RPE, and drusen-like deposits in the macula have been described. In post-mortem sections, an accumulation of iron associated with an enlarged RPE and loss of pigment of the RPE was observed (for a review, see [27]).

In animal models invalidated for the genes coding for iron-related proteins, an accumulation of iron in the RPE and PR is systematically observed as well as abnormalities in the RPE and PR degeneration $[25,35,39,52,131]$.

Studies carried out in aging rodents have shown that the increase in iron intakes in food or by intravenous injection leads to local iron deposits in the choroid, the RPE, and the segments of PR, as well as deposits of complement C3 in the Bruch's membrane, hypertrophy, and vacuolation of RPE and changes in the choriocapillaries [132,133].

\subsection{Age-Related Macular Degeneration}

AMD is a leading cause of worldwide blindness in the elderly population, affecting 200 million individuals by 2020 and nearly 300 million by 2040 [134]. The pathological aging of the macula can cause dry or non-neovascular and wet or neovascular AMD. At the early stage, accumulation of extracellular material forms drusen between the basal lamina of the RPE and the inner layer of Bruch's membrane in the eye. At the late stages, degeneration of the PR overlying the drusen can cause severe central vision loss in the dry form, whilst formation of new abnormal blood vessels from the choroid growing into the retina can cause subretinal fluid accumulation and bleeding. The wet form progresses rapidly and is responsible for $90 \%$ of severe vision loss associated with AMD. The pathogenesis of AMD is multifactorial, with genetic and environmental factors such as smoking. It is associated with dysregulations in the angiogenic, oxidative stress, lipid, inflammatory, and complement pathways [135]. Patients with early AMD have more iron in the macula than healthy patients. Iron deposits are found in the melanosomes of the choroid and the RPE, in the central layer of the calcified Bruch's membrane, in the drusen, and at the level of the PR [136]. Part of this iron, found in the pathological retina of AMD patients, is in the toxic free form [137]. Patients with dry AMD have more than twice the concentration of iron in their aqueous humor than in patients with cataract surgery [138]. The macular region of AMD patients with geographic atrophy showed an increase in the expression of proteins involved in iron homeostasis such as TF, FT, and FPN in the PR layer and feet MGC [139]. TF and CP mRNAs 
are increased in the two advanced forms of AMD [140]. In the serum of patients with the different forms of AMD, a significant increase in TF and TFR1 and a significant decrease in the concentration of soluble FT were observed while iron levels were unchanged [141]. Several polymorphisms of the iron homeostasis genes have been associated with risk factors for AMD: Tfr1, Tfr2 (obesity, tobacco) [142], Dmt1 [143], Irp1 and Irp2 [143], and heme oxygenases 1 and 2 (HO1/2) [144]. A recent study has shown that the expression of several miRNA, small non-coding RNA molecules binding in 3'UTR genes, was modified in the serum of AMD patients, especially those controlling the translation of the TFR1 and DMT1 proteins [145].

\subsection{Diabetic Retinopathy}

Diabetic retinopathy is a vision-threatening complication of diabetes affecting approximately 93 million in the middle-aged and elderly populations [146]. Chronic hyperglycemia causes progressive damage to retinal cells and to the retinal capillaries, leading to ischemia, VEGF-mediated retinal vascular abnormalization, and neovascular vessels that leak and bleed into the retina. Macular edema is also a major cause of vision loss in diabetic retinopathy [1]. Clinical reports have shown the link between iron levels in the vitreous and proliferative diabetic retinopathy $[124,147]$. A strong iron label was observed in the RPE and outer plexiform layer of patients with diabetic retinopathy [148]. In a mouse model of diabetic retinopathy, higher iron concentrations in the retina led to an increased expression of renin by a mechanism dependent on the GPR91 receptor [106].

\subsection{Glaucoma Neuropathy}

Glaucoma is increasingly a cause of irreversible blindness in the world. Its global prevalence is expected to be 76 million by 2020 and 112 million by 2040. Progressive damage to the optic nerve, leading to severe vision loss results from increased ocular pressure and other multiple favoring factors $[149,150]$. Although the link between iron and glaucoma is not yet fully understood, there is a change in iron homeostasis in glaucomatous eyes. TF concentration is increased in the aqueous humor [151], and mRNA of TF are increased in retina [152]. Whilst no differences were found in iron levels in aqueous humor of patients with primary open-angle glaucoma [153], serum levels of iron and FT were significantly increased [154,155], and serum CP level was lower [156]. A glaucomatous mice model had lower retinal iron concentrations than pre-glaucomatous DBA/2J and age-matched C57Bl/6J mice [157]. The expression of FT, CP, and TF was increased in monkey and rat glaucoma models $[152,158]$. In addition, the role of glutamate excitotoxicity in the pathogenesis of glaucoma is well documented; yet, there seems to be a link between the toxicity of glutamate and the increase in the entry of iron into neurons [159], and iron chelation seems to protect neurons against excitotoxicity and intraocular pressure-induced toxicity $[160,161]$. A mutation in the autophagy receptor optineurin is associated with the pathogenesis of glaucoma. It induces the degradation of the TFR1 and the Rab12-dependent autophagy mechanism leading to retinal ganglion cell death. The addition of iron in this model reduces cell death [162]. It seems that iron metabolism is dysregulated in glaucoma, but the exact role of iron is optic nerve damage and remains to be studied in the pathogenesis of glaucoma.

\subsection{Inherited Retinal Dystrophies and Associated Diseases}

Retinitis pigmentosa affects approximately 1.8 to 2.4 million people around the world. The disease is characterized by degeneration of the PR and progressive complete blindness [163]. Although iron has been shown to accumulate in several models of retinal degeneration, as in rd10 mouse or RCS rat $[86,164]$, the direct link between iron and retinitis pigmentosa has not been established in human disease.

Macular telangiectasia type 2 (MacTel 2) is a complex macular disease, characterized by abnormal perifoveal vessels (telangiectasia), loss of retinal organization, and ultimately loss of macula function. MacTel2 is the only human disease recognized as primarily associated with MGC cells loss. It has been shown that iron accumulates in the retina of patients with MacTel 2. In a murine model of MGC 
ablation that mimics part of MacTel 2 phenotype, there is also an accumulation of iron in retina and in the RPE [148]. Knowing the importance of MGC cells in the regulation of iron levels in the retina, it could be hypothesized that iron accumulates in MacTel 2 as a consequence of MGC loss in the fovea [165].

\section{Iron Neutralization as a Therapeutic Strategy for Retinal Diseases}

\subsection{Chemical Chelators}

Whether iron dysmetabolism in the retina is a cause or a consequence of various retinal diseases, iron accumulation is pathogenic, and its neutralization was shown to protect the retina from oxidative damage and retinal cell death in various models using different neutralizing strategies [133] (Table 2). As early as in the 1970s, an iron chelator, Deferroxamine, was used in humans to reduce the amount of "rust" deposited on the eye with satisfactory results. Used in many other models of retinal degeneration (retinitis pigmentosa [166] or light-induced retinal damage models [167]), this chelator reduces the iron load and preserves the retina. Other chelators, such as Deferriprone, have shown significant protection of the retina in mice with impaired mechanisms of iron homeostasis [168-171]. These chemical chelators are mainly used clinically to treat hemosiderosis induced by frequent transfusions. Administered orally, subcutaneously or intramuscularly, they could led to several eye side effects, including vision loss [172,173]. These side effects could be explained because chemical iron chelators also bind the iron necessary for RPE and PR function [133,174].

As highlighted in a recent review [175], the clinical use of chemical chelators is complex because they should (1) target only the organ or tissue which is affected by the iron excess; (2) have a sufficient half-life; (3) cross the different barriers that surround the tissue; and (4) have a rapid elimination route.

Table 2. Comparation between chemical iron chelators and transferrin in clinical use.

\begin{tabular}{ccccc}
\hline & Deferoxamine & Deferiprone & Deferasirox & Transferrin \\
\hline Iron Binding & $1: 1$ & $3: 1$ & $2: 1$ & $2: 1$ \\
\hline $\begin{array}{c}\text { Route of } \\
\text { administration }\end{array}$ & $\begin{array}{c}\text { Sub-cutaneous (every 8-12h) } \\
\text { Intravenous (IV) (5 days/week) }\end{array}$ & Oral (t.i.d) & Oral (q.d) & Intravenous [176] \\
\hline $\begin{array}{c}\text { Half-Life(after IV } \\
\text { administration) }\end{array}$ & 20-30 min & $3-4 \mathrm{~h}$ & $8-16 \mathrm{~h}$ & 4-8 d [176] \\
\hline Excretion & Urinary/fecal & Urinary & Fecal & Unknown \\
\hline $\begin{array}{c}\text { Usual Doses } \\
\text { (mg/Kg/d) }\end{array}$ & 25-60 [177] & 75-100 [177] & 20-40 [177] & 100 [176] \\
\hline $\begin{array}{c}\text { Acute iron intoxicationChronic } \\
\text { iron overload }\end{array}$ & $\begin{array}{c}\text { Chronic iron } \\
\text { overload }\end{array}$ & Chronic iron \\
overload & $\begin{array}{c}\text { Atransferrinemia [178] } \\
\text { Haematological stem } \\
\text { cell transplant [176] }\end{array}$ \\
\hline $\begin{array}{c}\text { Pigmentary retinopathy [173], } \\
\text { visual loss [179], impaired night } \\
\text { vision [180], optic neuritis [173] } \\
\text { and cataract [172]. }\end{array}$ & $\begin{array}{c}\text { Diplopia [181], } \\
\text { cataract [182] and } \\
\text { possible retinal } \\
\text { toxicity [183]. }\end{array}$ & $\begin{array}{c}\text { Lens opacities [184] } \\
\text { and retinal } \\
\text { disorders [185] }\end{array}$ & $\begin{array}{c}\text { No adverse effects } \\
\text { observed }\end{array}$ \\
\hline
\end{tabular}

Legend Table 2: Tid: 3 times a day; q.d: once a day.

\subsection{Natural Chelators}

Other natural molecules generally coming from plants, such as curcumin, polyphenols, and flavonoids, are iron chelators and have shown effectiveness in mouse models of retinal degeneration (for a review, see [186,187]).

\subsection{Transferrin}

TF is part of the TF superfamily, which also includes lactoferrin, melanotransferrin, and ovotransferrin, which are found in many species of both mammals and invertebrates. It consists in two lobes, each binding a $\mathrm{Fe}^{3+}$ atom with a very high affinity $\left(10^{22} \mathrm{M}^{-1}\right)$. Its primary role is to 
maintain an environment devoid of free iron. TF synthesized by RPE, PR, and neuronal cells is found in the aqueous and vitreous humors $[8,105]$. By single-cell RNA sequencing of human neural retina, mRNA for TF was enriched in peripheral retina compared to fovea [188]. Its expression is amplified during inflammation or immunity to increase the buffering capacity of iron. In light-induced retinal degeneration, TF and TFR1 mRNA increased in retina immediately after light exposure and then decreased at basal level. One day after light exposure, TF was increased, whereas TFR1 was reduced compared to not illuminated mice [32]. TF has long been of therapeutic interest due to its antimicrobial capacity and the ubiquitous presence of TFR1 allowing penetration of the blood-brain barrier [189]. TF has also been used successfully in humans in iron metabolism pathologies and for its cytoprotective capacity [190].

Our laboratory is interested in the potential of TF for the treatment of retinal pathologies (Table 3). Our work has shown that administration of the iron-free form (apoTF) by intraperitoneal injections in rd10 mice, a model of retinitis pigmentosa, preserves PRs better compared to the use of other chelators or antioxidants $[46,164]$. Injected into the vitreous, TF is present throughout the neural retina (MGC) and is eliminated via its receptors by RPE and the choroid without any immunogenic or toxic effect on the retina $[46,105]$. Thus, TF administered in a model of light-induced degeneration, allows the restoration of iron homeostasis, decreases iron accumulation, reduces inflammation and apoptosis, and preserves PRs and visual function [43]. In an ex vivo model of retinal detachment, TF inhibits the degenerative processes activated by the iron excess by reducing necrosis, apoptosis, gliosis, and oxidative stress. In vivo, human TF constitutively expressed in transgenic mice (TG) reduces loss of cones, cleavage of caspase 3, an apoptosis effector, DNA breaks, and necrosis (Figure 3). In rats, TF injected at the time of the detachment, reduces retinal edema, cell death and preserves PRs. In addition to its ability to reduce the accumulation of iron in the retina following detachment, TF also acts on other cellular pathways, no doubt through its interaction with molecular partners which remain to be discovered [105].

Table 3. Transferrin as a therapeutic drug in retinal diseases models.

\begin{tabular}{|c|c|c|c|c|}
\hline Model Experiment & Physiopathology & Administration Mode & Therapeutic Action of Transferrin & References \\
\hline $\begin{array}{l}\text { Primary culture of } \\
\text { Müller glial cells. }\end{array}$ & Iron exposure & $\begin{array}{l}\text { Cell isolation from transgenic } \\
\text { mice carrying the human } \\
\text { transferrin gene (TghTF) }\end{array}$ & $\begin{array}{l}\text { Cell number preservation. Lower necrosis revealed by } \\
\text { lactate dehydrogenase release. Inhibition of mRNA TF } \\
\text { diminution. }\end{array}$ & [46] \\
\hline $\begin{array}{l}\text { Primary culture of } \\
\text { Müller glial cells }\end{array}$ & Iron exposure & $\begin{array}{l}\text { Addition of apo- or } \\
\text { holo-human TF }\end{array}$ & $\begin{array}{l}\text { Dose-dependent cell number preservation by apo- but not } \\
\text { holo-human TF }\end{array}$ & [46] \\
\hline rd10 mice & $\begin{array}{l}\text { Model of retinitis } \\
\text { pigmentosa presenting iron } \\
\text { accumulation in } \\
\text { photoreceptors (PR) }\end{array}$ & $\begin{array}{l}\text { Crossing rd10 mice with } \\
\text { TghTF mice }\end{array}$ & $\begin{array}{c}\text { Preservation of retinal histology (outer and inner nuclear } \\
\text { layers thickness). } \\
\text { Less apoptotic-positive retinal cells.Conservation of rods } \\
\text { and cones morphology }\end{array}$ & [164] \\
\hline rd10 mice & $\begin{array}{l}\text { Model of retinitis } \\
\text { pigmentosa presenting iron } \\
\text { accumulation in PR }\end{array}$ & $\begin{array}{l}\text { Daily intraperitoneal } \\
\text { injections of apo-human TF }\end{array}$ & $\begin{array}{l}\text { Dose-dependent preservation of retinal histology (outer and } \\
\text { inner nuclear layers thickness). } \\
\text { Less apoptotic-positive retinal cells. } \\
\text { Conservation of rods and cones morphology }\end{array}$ & [164] \\
\hline $\begin{array}{l}\text { Light-induced } \\
\text { degeneration }\end{array}$ & $\begin{array}{l}\text { Model of acute degenerative } \\
\text { retina }\end{array}$ & $\begin{array}{l}\text { Intravitreal injection of } \\
\text { apo-human TF before and } \\
\text { after light-induced } \\
\text { degeneration }\end{array}$ & $\begin{array}{l}\text { Preservation of retinal histology and functions. } \\
\text { Preservation of ONL thickness and PR morphology. } \\
\text { Lower ONL apoptotic- positive cells.Regulation of iron } \\
\text { homeostasis balance. } \\
\text { Lower retinal iron accumulation and oxidative stress. } \\
\text { Regulation of retina inflammation and diminution of } \\
\text { microglial cells activation in outer retina. }\end{array}$ & [43] \\
\hline $\begin{array}{l}\text { Light-induced } \\
\text { degeneration }\end{array}$ & $\begin{array}{l}\text { Model of acute degenerative } \\
\text { retina }\end{array}$ & $\begin{array}{l}\text { Electrotransfer of cDNA of } \\
\text { human TF for in oculo } \\
\text { production }\end{array}$ & Preservation of retinal histology and ONL layer thickness. & [43] \\
\hline $\mathrm{P} 23 \mathrm{H}$ rats & $\begin{array}{l}\text { Model of retinitis } \\
\text { pigmentosa }\end{array}$ & $\begin{array}{l}\text { Electrotransfer of cDNA of } \\
\text { human TF for in oculo } \\
\text { production }\end{array}$ & Preservation of retinal histology and ONL layer thickness. & [43] \\
\hline $\begin{array}{l}\text { Bone } \\
\text { morphogenetic } \\
\text { protein } 6 \text { mice }\end{array}$ & $\begin{array}{l}\text { Model of hemochromatosis } \\
\text { with retinal iron } \\
\text { accumulation }\end{array}$ & $\begin{array}{l}\text { Intraperitoneal and } \\
\text { intravitreal injections of } \\
\text { apo-human TF }\end{array}$ & $\begin{array}{l}\text { Diminution of iron accumulation in retina pigment } \\
\text { epithelium }\end{array}$ & [43] \\
\hline
\end{tabular}


Table 3. Cont.

\begin{tabular}{|c|c|c|c|c|}
\hline Model Experiment & Physiopathology & Administration Mode & Therapeutic Action of Transferrin & References \\
\hline $\begin{array}{l}\text { Retinal explant of } \\
\text { mice }\end{array}$ & $\begin{array}{l}\text { Retinal detachment with } \\
\text { iron exposure }\end{array}$ & Retinas from TghTF & $\begin{array}{c}\text { Preservation of cones number and rod outer segments } \\
\text { length. } \\
\text { Lower necrosis } \\
\text { Prevention of iron retinal accumulation }\end{array}$ & [105] \\
\hline $\begin{array}{l}\text { Retinal explant of } \\
\text { rats }\end{array}$ & $\begin{array}{l}\text { Retinal detachment with } \\
\text { iron exposure }\end{array}$ & $\begin{array}{l}\text { Addition of apo-human TF } \\
\text { after iron exposure }\end{array}$ & $\begin{array}{c}\text { Preservation of rhodopsin expression level and cones } \\
\text { number } \\
\text { Lower necrosis and apoptosis } \\
\text { Prevention of retinal iron accumulation }\end{array}$ & [105] \\
\hline $\begin{array}{l}\text { Subretinal injection } \\
\text { of hyaluronic acid } \\
\text { in mice }\end{array}$ & $\begin{array}{l}\text { Retinal detachment } \\
\text { presenting iron } \\
\text { accumulation in subretinal } \\
\text { space }\end{array}$ & TghTF mice & $\begin{array}{l}\text { Preservation of retinal histology, rods outer segments length } \\
\text { and number of cones Diminution of retinal oedema and } \\
\text { Müller glial cells activation } \\
\text { Lower apoptosis and necrosis } \\
\text { Regulation of pathways involved in biological functions }\end{array}$ & [105] \\
\hline $\begin{array}{l}\text { Subretinal injection } \\
\text { of hyaluronic acid } \\
\text { in rats }\end{array}$ & $\begin{array}{l}\text { Retinal detachment } \\
\text { presenting iron } \\
\text { accumulation in subretinal } \\
\text { space }\end{array}$ & $\begin{array}{l}\text { Intravitreal injection of } \\
\text { apo-hTF }\end{array}$ & $\begin{array}{c}\text { Preservation of retinal histology, rods outer segments length } \\
\text { Diminution of retinal oedema }\end{array}$ & [105] \\
\hline
\end{tabular}

Legend Table 3: ApoTF: transferrin without iron; HoloTF: transferrin binding iron; INL: inner nuclear layer; ONL: outer nuclear layer; PR: photoreceptors; TF: transferrin; TghTf: transgenic mice carrying the complete human transferrin gene.

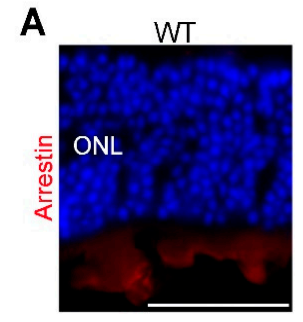

B

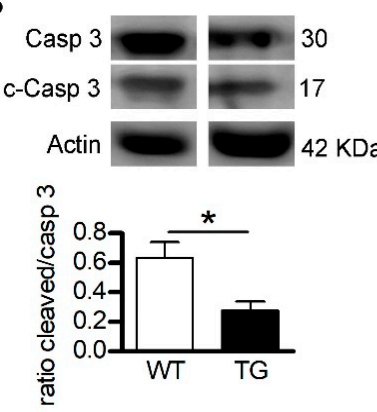

D

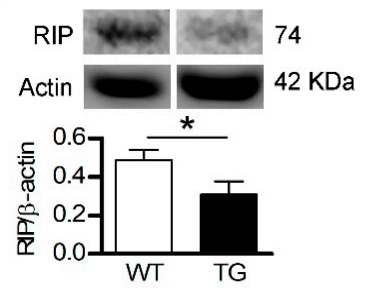

C
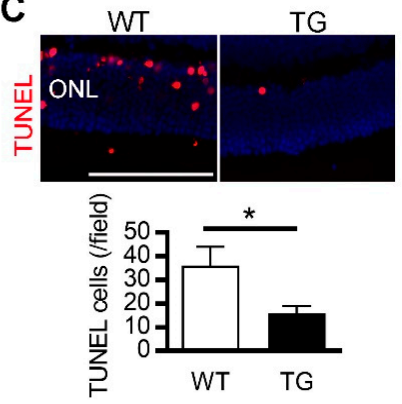

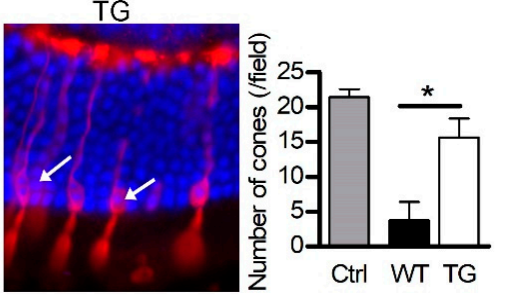

Figure 3. Transferrin expression preserves the detached retina. Legend Figure 3: After retinal detachment (RD), photoreceptors died by apoptosis and necrosis. Transgenic mice (TG) expressing human transferrin (TF) were used to demonstrate the protective effects of TF. (A) Arrestin staining revealed cones in retinal sections of TG mice (arrows) after RD. Cone number was higher in TG compared with WT mice. (B) The ratio of cleaved/pro-caspase 3 protein level was lower in TG mice compared to WT mice after RD. (C) The number of nuclei positive apoptotic-DNA breaks, stained by TUNEL, was reduced in TG mice compared to WT mice. (D) Necrotic RIP kinase protein level was reduced in TG mice compared with WT mice. All values are represented as the mean \pm SEM. Mann-Whitney test $(n=3-6){ }^{*} p \leq 0.025$. ONL: Outer nuclear layer. Scale bar, $100 \mu \mathrm{m}$. From [105]. Reprinted with permission from AAAS. 


\section{Conclusions}

Iron is one of the most common elements on Earth. Two-hundred years ago, it was discovered that, after desiccation, the residual ashes of an aged human retina could be mobilized by a magnet (as quoted in [191]). Nowadays the chemical study of iron structure and its outer electrons has been revealed by the discovery of quantum effects of iron electron in biology. The best illustrations have been described by Cedric Weber who demonstrated that very specific quantum effects are involved to explain the energy in the binding of iron to oxygen and CO to hemoglobin [192]. This transition metal plays a main role in retinal physiology, but overload leads to retinal degeneration and loss of function. Iron chelation is a potential therapeutic target to prevent retinal degeneration. TF, as an endogenous iron binding protein, avoids toxic effects of iron depletion and activates additional neuroprotective pathways.

Author Contributions: Conceptualization: E.P., Y.C., F.B.-C.; literature search: E.P., A.D.; J.Y., Y.C., F.B.-C.; figure and tables: E.P., J.Y.; writing - original draft preparation E.P., A.D.; Y.C., F.B.-C.; writing—review and editing: E.P., A.D.; Y.C., F.B.-C. All authors have read and agreed to the published version of the manuscript.

Funding: This research received no external funding.

Acknowledgments: We sincerely thank Jean-Claude Jeanny and Marina Yefimova for their significant contribution in the initial description of iron and iron-related proteins in retina.

Conflicts of Interest: Y.C., E.P. and F.B.C. are cited as inventor on a patent for the use of transferrin for the treatment of eye diseases.

\section{Abbreviations}

$\mathrm{ABC}$

AMD

APP

BMP

BRB

CEC

$\mathrm{CP}$

DFO

DMT1

Fe-S

FPN

FT

HEPC

$\mathrm{HEPH}$

HFE

HFT

HIF

HJV

HRE

IL

IRE

IRP

LCN2

LF

LFT

LIP

MacTel 2

MGC

NTBI
ATP binding cassette

Age-Related Macular Degeneration

amyloid-beta precursor protein

Bone Morphogenetic Protein

Blood Retinal Barrier

Choroidal Endothelial Cell

Ceruloplasmin

Deferroxamine

divalent metal transporter 1

Cluster Iron-Sulfur

Ferroportin

Ferritin

Hepcidin

Hephaestin

Hemochromatosis protein

Heavy Ferritin chin

Hypoxia Inducible Factor

Hemojuveline

Hypoxia Responsive Element

Interleukin

Iron Responsive Element

Iron Regulatory Protein

Lipocalin 2

Lactoferrin

Light Ferritin chain

Labile Iron Pool

Macular telangiectasia type 2

Muller Glial cell

Non-Transferrin Bound Iron 


$\begin{array}{ll}\text { NLRP3 } & \text { NOD-like receptor family, pyrin domain containing 3 } \\ \text { PCBP } & \text { Poly(rC)-binding proteins } \\ \text { PrPC } & \text { Prion protein } \\ \text { PR } & \text { photoreceptor } \\ \text { REC } & \text { Retinal Endothelial Cell } \\ \text { ROS } & \text { Reactive Oxygen Species } \\ \text { RPE } & \text { Retinal Pigment Epithelium } \\ \text { SCARA5 } & \text { Scavenger receptor class A, member 5 } \\ \text { SMAD } & \text { Mothers against decapentaplegic homolog } 1 \\ \text { TBI } & \text { Transferrin Bound Iron } \\ \text { TF } & \text { Transferrin } \\ \text { TFR } & \text { Transferrin Receptor } \\ \text { VEGF } & \text { Vascular Endothelial Growth Factor } \\ \text { ZP } & \text { Zyloklopen } \\ \text { ZIP } & \text { ZRT/IRT-like proteins }\end{array}$

\section{References}

1. Daruich, A.; Matet, A.; Moulin, A.; Kowalczuk, L.; Nicolas, M.; Sellam, A.; Rothschild, P.-R.; Omri, S.; Gélizé, E.; Jonet, L.; et al. Mechanisms of macular edema: Beyond the surface. Prog. Retin. Eye Res. 2018, 63, 20-68. [CrossRef] [PubMed]

2. Anderson, B.; Saltzman, H.A. RETINAL OXYGEN UTILIZATION MEASURED BY HYPERBARIC BLACKOUT. Arch. Ophthalmol. 1964, 72, 792-795. [CrossRef] [PubMed]

3. Linsenmeier, R.A.; Zhang, H.F. Retinal oxygen: From animals to humans. Prog. Retin. Eye Res. 2017, 58, 115-151. [CrossRef] [PubMed]

4. Wang, L.; Törnquist, P.; Bill, A. Glucose metabolism in pig outer retina in light and darkness. Acta Physiol. Scand. 1997, 160, 75-81. [CrossRef] [PubMed]

5. Hurley, J.B.; Lindsay, K.J.; Du, J. Glucose, lactate, and shuttling of metabolites in vertebrate retinas. J. Neurosci. Res. 2015, 93, 1079-1092. [CrossRef] [PubMed]

6. Kurihara, T. Development and pathological changes of neurovascular unit regulated by hypoxia response in the retina. Prog. Brain Res. 2016, 225, 201-211.

7. Yang, L.; Wang, D.; Wang, X.-T.; Lu, Y.-P.; Zhu, L. The roles of hypoxia-inducible Factor-1 and iron regulatory protein 1 in iron uptake induced by acute hypoxia. Biochem. Biophys. Res. Commun. 2018, 507, 128-135. [CrossRef]

8. Yefimova, M.G.; Jeanny, J.C.; Guillonneau, X.; Keller, N.; Nguyen-Legros, J.; Sergeant, C.; Guillou, F.; Courtois, Y. Iron, ferritin, transferrin, and transferrin receptor in the adult rat retina. Investig. Ophthalmol. Vis. Sci. 2000, 41, 2343-2351.

9. Garcia-Castineiras, S. Iron, the retina and the lens: A focused review. Exp. Eye Res. 2010, 90, 664-678. [CrossRef]

10. Moos, T.; Bernth, N.; Courtois, Y.; Morgan, E.H. Developmental iron uptake and axonal transport in the retina of the rat. Mol. Cell. Neurosci. 2011, 46, 607-613. [CrossRef]

11. Hahn, P.; Song, Y.; Ying, G.S.; He, X.; Beard, J.; Dunaief, J.L. Age-dependent and gender-specific changes in mouse tissue iron by strain. Exp. Gerontol. 2009, 44, 594-600. [CrossRef] [PubMed]

12. Hahn, P.; Ying, G.S.; Beard, J.; Dunaief, J.L. Iron levels in human retina: Sex difference and increase with age. Neuroreport 2006, 17, 1803-1806. [CrossRef] [PubMed]

13. Ugarte, M.; Osborne, N.N.; Brown, L.A.; Bishop, P.N. Iron, zinc, and copper in retinal physiology and disease. Surv. Ophthalmol. 2013, 58, 585-609. [CrossRef] [PubMed]

14. Chen, H.; Liu, B.; Lukas, T.J.; Suyeoka, G.; Wu, G.; Neufeld, A.H. Changes in iron-regulatory proteins in the aged rodent neural retina. Neurobiol. Aging 2009, 30, 1865-1876. [CrossRef] [PubMed]

15. Chen, H.; Lukas, T.J.; Du, N.; Suyeoka, G.; Neufeld, A.H. Dysfunction of the retinal pigment epithelium with age: Increased iron decreases phagocytosis and lysosomal activity. Investig. Ophthalmol. Vis. Sci. 2009, 50, 1895-1902. [CrossRef] [PubMed] 
16. Lane, D.J.R.; Merlot, A.M.; Huang, M.L.-H.; Bae, D.-H.; Jansson, P.J.; Sahni, S.; Kalinowski, D.S.; Richardson, D.R. Cellular iron uptake, trafficking and metabolism: Key molecules and mechanisms and their roles in disease. Biochim. Biophys. Acta (BBA) - Mol. Cell Res. 2015, 1853, 1130-1144. [CrossRef]

17. Lederman, M.; Obolensky, A.; Grunin, M.; Banin, E.; Chowers, I. Retinal Function and Structure in the Hypotransferrinemic Mouse. Investig. Opthalmol. Vis. Sci. 2012, 53, 605. [CrossRef]

18. Rageh, A.A.; Ferrington, D.A.; Roehrich, H.; Yuan, C.; Terluk, M.R.; Nelson, E.F.; Montezuma, S.R. Lactoferrin Expression in Human and Murine Ocular Tissue. Curr. Eye Res. 2016, 41, 883-889. [CrossRef]

19. Montezuma, S.R.; Dolezal, L.D.; Rageh, A.A.; Mar, K.; Jordan, M.; Ferrington, D.A. Lactoferrin Reduces Chorioretinal Damage in the Murine Laser Model of Choroidal Neovascularization. Curr. Eye Res. 2015, 40, 946-953. [CrossRef]

20. Parmar, T.; Parmar, V.M.; Arai, E.; Sahu, B.; Perusek, L.; Maeda, A. Acute Stress Responses Are Early Molecular Events of Retinal Degeneration in Abca4-/-Rdh8-/- Mice After Light Exposure. Investig. Ophthalmol. Vis. Sci. 2016, 57, 3257-3267. [CrossRef]

21. Parmar, T.; Parmar, V.M.; Perusek, L.; Georges, A.; Takahashi, M.; Crabb, J.W.; Maeda, A. Lipocalin 2 Plays an Important Role in Regulating Inflammation in Retinal Degeneration. J. Immunol. 2018, 200, 3128-3141. [CrossRef] [PubMed]

22. Cases, O.; Obry, A.; Ben-Yacoub, S.; Augustin, S.; Joseph, A.; Toutirais, G.; Simonutti, M.; Christ, A.; Cosette, P.; Kozyraki, R. Impaired vitreous composition and retinal pigment epithelium function in the FoxG1::LRP2 myopic mice. Biochim. Biophys. Acta 2017, 1863, 1242-1254. [CrossRef] [PubMed]

23. Hahn, P.; Dentchev, T.; Qian, Y.; Rouault, T.; Harris, Z.L.; Dunaief, J.L. Immunolocalization and regulation of iron handling proteins ferritin and ferroportin in the retina. Mol. Vis. 2004, 10, 598-607. [PubMed]

24. Theurl, M.; Song, D.; Clark, E.; Sterling, J.; Grieco, S.; Altamura, S.; Galy, B.; Hentze, M.; Muckenthaler, M.U.; Dunaief, J.L. Mice with hepcidin-resistant ferroportin accumulate iron in the retina. FASEB J. 2016, 30, 813-823. [CrossRef] [PubMed]

25. Hahn, P.; Qian, Y.; Dentchev, T.; Chen, L.; Beard, J.; Harris, Z.L.; Dunaief, J.L. Disruption of ceruloplasmin and hephaestin in mice causes retinal iron overload and retinal degeneration with features of age-related macular degeneration. Proc. Natl. Acad. Sci. USA 2004, 101, 13850-13855. [CrossRef]

26. Wolkow, N.; Song, D.; Song, Y.; Chu, S.; Hadziahmetovic, M.; Lee, J.C.; Iacovelli, J.; Grieco, S.; Dunaief, J.L. Ferroxidase hephaestin's cell-autonomous role in the retinal pigment epithelium. Am. J. Pathol. 2012, 180, 1614-1624. [CrossRef]

27. Wolkow, N.; Song, Y.; Wu, T.-D.; Qian, J.; Guerquin-Kern, J.-L.; Dunaief, J.L. Aceruloplasminemia: Retinal histopathologic manifestations and iron-mediated melanosome degradation. Arch. Ophthalmol. 2011, 129, 1466-1474. [CrossRef]

28. Dinet, V.; An, N.; Ciccotosto, G.D.; Bruban, J.; Maoui, A.; Bellingham, S.A.; Hill, A.F.; Andersen, O.M.; Nykjaer, A.; Jonet, L.; et al. APP involvement in retinogenesis of mice. Acta Neuropathol. 2011, 121, 351-363. [CrossRef]

29. Chen, H.; Attieh, Z.K.; Syed, B.A.; Kuo, Y.; Stevens, V.; Fuqua, B.K.; Andersen, H.S.; Naylor, C.E.; Evans, R.W.; Gambling, L.; et al. Identification of Zyklopen, a New Member of the Vertebrate Multicopper Ferroxidase Family, and Characterization in Rodents and Human Cells123. J. Nutr. 2010, 140, 1728-1735. [CrossRef]

30. He, X.; Hahn, P.; Iacovelli, J.; Wong, R.; King, C.; Bhisitkul, R.; Massaro-Giordano, M.; Dunaief, J.L. Iron homeostasis and toxicity in retinal degeneration. Prog. Retin. Eye Res. 2007, 26, 649-673. [CrossRef]

31. Sterling, J.; Guttha, S.; Song, Y.; Song, D.; Hadziahmetovic, M.; Dunaief, J.L. Iron importers Zip8 and Zip14 are expressed in retina and regulated by retinal iron levels. Exp. Eye Res. 2017, 155, 15-23. [CrossRef] [PubMed]

32. Picard, E.; Ranchon-Cole, I.; Jonet, L.; Beaumont, C.; Behar-Cohen, F.; Courtois, Y.; Jeanny, J.-C. Light-induced retinal degeneration correlates with changes in iron metabolism gene expression, ferritin level, and aging. Investig. Ophthalmol. Vis. Sci. 2011, 52, 1261-1274. [CrossRef] [PubMed]

33. Martin, P.M.; Gnana-Prakasam, J.P.; Roon, P.; Smith, R.G.; Smith, S.B.; Ganapathy, V. Expression and polarized localization of the hemochromatosis gene product HFE in retinal pigment epithelium. Investig. Ophthalmol. Vis. Sci. 2006, 47, 4238-4244. [CrossRef] [PubMed]

34. Gnana-Prakasam, J.P.; Thangaraju, M.; Liu, K.; Ha, Y.; Martin, P.M.; Smith, S.B.; Ganapathy, V. Absence of iron-regulatory protein Hfe results in hyperproliferation of retinal pigment epithelium: Role of cystine/glutamate exchanger. Biochem. J. 2009, 424, 243-252. [CrossRef] [PubMed] 
35. Hadziahmetovic, M.; Song, Y.; Wolkow, N.; Iacovelli, J.; Kautz, L.; Roth, M.P.; Dunaief, J.L. Bmp6 regulates retinal iron homeostasis and has altered expression in age-related macular degeneration. Am. J. Pathol. 2011, 179, 335-348. [CrossRef] [PubMed]

36. Gnana-Prakasam, J.P.; Zhang, M.; Martin, P.M.; Atherton, S.S.; Smith, S.B.; Ganapathy, V. Expression of the iron-regulatory protein haemojuvelin in retina and its regulation during cytomegalovirus infection. Biochem. J. 2009, 419, 533-543. [CrossRef] [PubMed]

37. Tawfik, A.; Gnana-Prakasam, J.P.; Smith, S.B.; Ganapathy, V. Deletion of hemojuvelin, an iron-regulatory protein, in mice results in abnormal angiogenesis and vasculogenesis in retina along with reactive gliosis. Investig. Ophthalmol. Vis. Sci. 2014, 55, 3616-3625. [CrossRef] [PubMed]

38. Gnana-Prakasam, J.P.; Baldowski, R.B.; Ananth, S.; Martin, P.M.; Smith, S.B.; Ganapathy, V. Retinal expression of the serine protease matriptase-2 (Tmprss6) and its role in retinal iron homeostasis. Mol. Vis. 2014, 20, 561-574. [PubMed]

39. Hadziahmetovic, M.; Song, Y.; Ponnuru, P.; Iacovelli, J.; Hunter, A.; Haddad, N.; Beard, J.; Connor, J.R.; Vaulont, S.; Dunaief, J.L. Age-Dependent Retinal Iron Accumulation and Degeneration in Hepcidin Knockout Mice. Investig. Ophthalmol. Vis. Sci. 2011, 52, 109-118. [CrossRef] [PubMed]

40. Kast, B.; Schori, C.; Grimm, C. Hypoxic preconditioning protects photoreceptors against light damage independently of hypoxia inducible transcription factors in rods. Exp. Eye Res. 2016, 146, 60-71. [CrossRef]

41. Hughes, J.M.; Groot, A.J.; van der Groep, P.; Sersansie, R.; Vooijs, M.; van Diest, P.J.; Van Noorden, C.J.F.; Schlingemann, R.O.; Klaassen, I. Active HIF-1 in the normal human retina. J. Histochem. Cytochem. 2010, 58, 247-254. [CrossRef]

42. Perez Bay, A.E.; Schreiner, R.; Benedicto, I.; Rodriguez-Boulan, E.J. Galectin-4-mediated transcytosis of transferrin receptor. J. Cell. Sci. 2014, 127, 4457-4469. [CrossRef] [PubMed]

43. Picard, E.; Le Rouzic, Q.; Oudar, A.; Berdugo, M.; El Sanharawi, M.; Andrieu-Soler, C.; Naud, M.C.; Jonet, L.; Latour, C.; Klein, C.; et al. Targeting iron-mediated retinal degeneration by local delivery of transferrin. Free Radic. Biol. Med. 2015, 89, 1105-1121. [CrossRef] [PubMed]

44. Kaczara, P.; Zaręba, M.; Herrnreiter, A.; Skumatz, C.M.B.; Żądło, A.; Sarna, T.; Burke, J.M. Melanosome-iron interactions within retinal pigment epithelium-derived cells. Pigment Cell Melanoma Res. 2012, 25, 804-814. [CrossRef] [PubMed]

45. Baumann, B.H.; Shu, W.; Song, Y.; Simpson, E.M.; Lakhal-Littleton, S.; Dunaief, J.L. Ferroportin-mediated iron export from vascular endothelial cells in retina and brain. Exp. Eye Res. 2019, 187, 107728. [CrossRef] [PubMed]

46. Picard, E.; Fontaine, I.; Jonet, L.; Guillou, F.; Behar-Cohen, F.; Courtois, Y.; Jeanny, J.C. The protective role of transferrin in Muller glial cells after iron-induced toxicity. Mol. Vis. 2008, 14, 928-941. [PubMed]

47. Mendes-Jorge, L.; Ramos, D.; Valença, A.; López-Luppo, M.; Pires, V.M.R.; Catita, J.; Nacher, V.; Navarro, M.; Carretero, A.; Rodriguez-Baeza, A.; et al. Correction: L-Ferritin Binding to Scara5: A New Iron Traffic Pathway Potentially Implicated in Retinopathy. PLoS ONE 2017, 12, e0180288. [CrossRef]

48. Rousseau, E.; Michel, P.P.; Hirsch, E.C. The Iron-Binding Protein Lactoferrin Protects Vulnerable Dopamine Neurons from Degeneration by Preserving Mitochondrial Calcium Homeostasis. Mol. Pharm. 2013, 84, 888-898. [CrossRef]

49. Valapala, M.; Edwards, M.; Hose, S.; Grebe, R.; Bhutto, I.A.; Cano, M.; Berger, T.; Mak, T.W.; Wawrousek, E.; Handa, J.T.; et al. Increased Lipocalin-2 in the retinal pigment epithelium of Cryba1 cKO mice is associated with a chronic inflammatory response. Aging Cell 2014, 13, 1091-1094. [CrossRef]

50. Ananth, S.; Gnana-Prakasam, J.P.; Bhutia, Y.D.; Veeranan-Karmegam, R.; Martin, P.M.; Smith, S.B.; Ganapathy, V. Regulation of the cholesterol efflux transporters ABCA1 and ABCG1 in retina in hemochromatosis and by the endogenous siderophore 2,5-dihydroxybenzoic acid. Biochim. Biophys. Acta (BBA) - Mol. Basis Dis. 2014, 1842, 603-612. [CrossRef]

51. Anderson, C.P.; Shen, M.; Eisenstein, R.S.; Leibold, E.A. Mammalian iron metabolism and its control by iron regulatory proteins. Biochim. Biophys. Acta 2012, 1823, 1468-1483. [CrossRef] [PubMed]

52. Baumann, B.H.; Shu, W.; Song, Y.; Sterling, J.; Kozmik, Z.; Lakhal-Littleton, S.; Dunaief, J.L. Liver-Specific, but Not Retina-Specific, Hepcidin Knockout Causes Retinal Iron Accumulation and Degeneration. Am. J. Pathol. 2019, 189, 1814-1830. [CrossRef] [PubMed] 
53. Mowat, F.M.; Luhmann, U.F.O.; Smith, A.J.; Lange, C.; Duran, Y.; Harten, S.; Shukla, D.; Maxwell, P.H.; Ali, R.R.; Bainbridge, J.W.B. HIF-1alpha and HIF-2alpha Are Differentially Activated in Distinct Cell Populations in Retinal Ischaemia. PLoS ONE 2010, 5, e11103. [CrossRef] [PubMed]

54. Maio, N.; Rouault, T.A. Iron-sulfur cluster biogenesis in mammalian cells: New insights into the molecular mechanisms of cluster delivery. Biochim. Biophys. Acta 2015, 1853, 1493-1512. [CrossRef]

55. Das, D.; Patra, S.; Bridwell-Rabb, J.; Barondeau, D.P. Mechanism of frataxin "bypass" in human iron-sulfur cluster biosynthesis with implications for Friedreich's ataxia. J. Biol. Chem. 2019, 294, 9276-9284. [CrossRef] [PubMed]

56. Efimova, M.G.; Trottier, Y. Distribution of frataxin in eye retina of normal mice and of transgenic R7E mice with retinal degeneration. J. Evol. Biochem. Phys. 2010, 46, 414-417. [CrossRef]

57. Crombie, D.E.; Van Bergen, N.; Davidson, K.C.; Anjomani Virmouni, S.; Mckelvie, P.A.; Chrysostomou, V.; Conquest, A.; Corben, L.A.; Pook, M.A.; Kulkarni, T.; et al. Characterization of the retinal pigment epithelium in Friedreich ataxia. Biochem. Biophys. Rep. 2015, 4, 141-147. [CrossRef]

58. Rouault, T.A.; Maio, N. Biogenesis and functions of mammalian iron-sulfur proteins in the regulation of iron homeostasis and pivotal metabolic pathways. J. Biol. Chem. 2017, 292, 12744-12753. [CrossRef]

59. Crack, J.C.; Green, J.; Thomson, A.J.; Brun, N.E.L. Iron-Sulfur Clusters as Biological Sensors: The Chemistry of Reactions with Molecular Oxygen and Nitric Oxide. Acc. Chem. Res. 2014, 47, 3196-3205. [CrossRef]

60. Puig, S.; Ramos-Alonso, L.; Romero, A.M.; Martínez-Pastor, M.T. The elemental role of iron in DNA synthesis and repair. Metallomics 2017, 9, 1483-1500. [CrossRef]

61. Paul, V.D.; Lill, R. Biogenesis of cytosolic and nuclear iron-sulfur proteins and their role in genome stability. Biochim. Biophys. Acta 2015, 1853, 1528-1539. [CrossRef] [PubMed]

62. Luo, H.; Zhou, M.; Ji, K.; Zhuang, J.; Dang, W.; Fu, S.; Sun, T.; Zhang, X. Expression of Sirtuins in the Retinal Neurons of Mice, Rats, and Humans. Front. Aging Neurosci. 2017, 9, 366. [CrossRef] [PubMed]

63. Zhao, Z.; Chen, Y.; Wang, J.; Sternberg, P.; Freeman, M.L.; Grossniklaus, H.E.; Cai, J. Age-Related Retinopathy in NRF2-Deficient Mice. PLoS ONE 2011, 6, e19456. [CrossRef]

64. Alexeyev, M.; Shokolenko, I.; Wilson, G.; LeDoux, S. The Maintenance of Mitochondrial DNA Integrity-Critical Analysis and Update. Cold Spring Harb. Perspect. Biol. 2013, 5, a012641. [CrossRef] [PubMed]

65. Ballinger, S.W.; Van Houten, B.; Jin, G.F.; Conklin, C.A.; Godley, B.F. Hydrogen peroxide causes significant mitochondrial DNA damage in human RPE cells. Exp. Eye Res. 1999, 68, 765-772. [CrossRef] [PubMed]

66. Barreau, E.; Brossas, J.-Y.; Courtois, Y.; Treton, J.A. Accumulation of Mitochondrial DNA Deletions in Human Retina During Aging. Investig. Ophthalmol. Vis. Sci. 1996, 37, 384-391.

67. Gkotsi, D.; Begum, R.; Salt, T.; Lascaratos, G.; Hogg, C.; Chau, K.-Y.; Schapira, A.H.V.; Jeffery, G. Recharging mitochondrial batteries in old eyes. Near infra-red increases ATP. Exp. Eye Res. 2014, 122, 50-53. [CrossRef]

68. Tezel, T.H.; Geng, L.; Lato, E.B.; Schaal, S.; Liu, Y.; Dean, D.; Klein, J.B.; Kaplan, H.J. Synthesis and Secretion of Hemoglobin by Retinal Pigment Epithelium. Investig. Opthalmol. Vis. Sci. 2009, 50, 1911. [CrossRef]

69. Promsote, W.; Makala, L.; Li, B.; Smith, S.B.; Singh, N.; Ganapathy, V.; Pace, B.S.; Martin, P.M. Monomethylfumarate Induces $\gamma$-Globin Expression and Fetal Hemoglobin Production in Cultured Human Retinal Pigment Epithelial (RPE) and Erythroid Cells, and in Intact Retina. Investig. Opthalmol. Vis. Sci. 2014, 55, 5382. [CrossRef]

70. Hunt, R.C.; Hunt, D.M.; Gaur, N.; Smith, A. Hemopexin in the human retina: Protection of the retina against heme-mediated toxicity. J. Cell. Physiol. 1996, 168, 71-80. [CrossRef]

71. Chen, W.; Lu, H.; Dutt, K.; Smith, A.; Hunt, D.M.; Hunt, R.C. Expression of the protective proteins hemopexin and haptoglobin by cells of the neural retina. Exp. Eye Res. 1998, 67, 83-93. [CrossRef] [PubMed]

72. Ascenzi, P.; di Masi, A.; Leboffe, L.; Fiocchetti, M.; Nuzzo, M.T.; Brunori, M.; Marino, M. Neuroglobin: From structure to function in health and disease. Mol. Asp. Med. 2016, 52, 1-48. [CrossRef] [PubMed]

73. Tao, Y.; Ma, Z.; Liu, B.; Fang, W.; Qin, L.; Huang, Y.F.; Wang, L.; Gao, Y. Hemin supports the survival of photoreceptors injured by N-Methyl-N-nitrosourea: The contributory role of neuroglobin in photoreceptor degeneration. Brain Res. 2018, 1678, 47-55. [CrossRef] [PubMed]

74. Yu, Z.-L.; Qiu, S.; Chen, X.-C.; Dai, Z.-H.; Huang, Y.-C.; Li, Y.-N.; Cai, R.-H.; Lei, H.-T.; Gu, H.-Y. Neuroglobin - A potential biological marker of retinal damage induced by LED light. Neuroscience 2014, 270, 158-167. [CrossRef]

75. Jin, K.; Mao, X.; Xie, L.; Greenberg, D.A. Interactions between Vascular Endothelial Growth Factor and Neuroglobin. Neurosci. Lett. 2012, 519, 47-50. [CrossRef] 
76. Gnana-Prakasam, J.P.; Reddy, S.K.; Veeranan-Karmegam, R.; Smith, S.B.; Martin, P.M.; Ganapathy, V. Polarized distribution of heme transporters in retinal pigment epithelium and their regulation in the iron-overload disease hemochromatosis. Investig. Ophthalmol. Vis. Sci. 2011, 52, 9279-9286. [CrossRef]

77. Moiseyev, G.; Takahashi, Y.; Chen, Y.; Gentleman, S.; Redmond, T.M.; Crouch, R.K.; Ma, J.-X. RPE65 is an iron(II)-dependent isomerohydrolase in the retinoid visual cycle. J. Biol. Chem. 2006, 281, 2835-2840. [CrossRef]

78. Hamel, C.P.; Tsilou, E.; Pfeffer, B.A.; Hooks, J.J.; Detrick, B.; Redmond, T.M. Molecular cloning and expression of RPE65, a novel retinal pigment epithelium-specific microsomal protein that is post-transcriptionally regulated in vitro. J. Biol. Chem. 1993, 268, 15751-15757.

79. Marlhens, F.; Bareil, C.; Griffoin, J.M.; Zrenner, E.; Amalric, P.; Eliaou, C.; Liu, S.Y.; Harris, E.; Redmond, T.M.; Arnaud, B.; et al. Mutations in RPE65 cause Leber's congenital amaurosis. Nat. Genet. 1997, 17, 139-141. [CrossRef]

80. Shyam, R.; Gorusupudi, A.; Nelson, K.; Horvath, M.P.; Bernstein, P.S. RPE65 has an additional function as the lutein to meso -zeaxanthin isomerase in the vertebrate eye. Proc. Natl. Acad. Sci. USA 2017, 114, 10882-10887. [CrossRef]

81. Betts-Obregon, B.S.; Gonzalez-Fernandez, F.; Tsin, A.T. Interphotoreceptor retinoid-binding protein (IRBP) promotes retinol uptake and release by rat Müller cells (rMC-1) in vitro: Implications for the cone visual cycle. Investig. Ophthalmol. Vis. Sci. 2014, 55, 6265-6271. [CrossRef]

82. Unger, E.L.; Earley, C.J.; Beard, J.L. Diurnal cycle influences peripheral and brain iron levels in mice. J. Appl. Physiol. 2009, 106, 187-193. [CrossRef] [PubMed]

83. Unger, E.L.; Jones, B.C.; Bianco, L.E.; Allen, R.P.; Earley, C.J. Diurnal variations in brain iron concentrations in BXD RI mice. Neuroscience 2014, 263, 54-59. [CrossRef] [PubMed]

84. Lim, S.; Scholten, A.; Manchala, G.; Cudia, D.; Zlomke-Sell, S.-K.; Koch, K.-W.; Ames, J.B. Structural Characterization of Ferrous Ion Binding to Retinal Guanylate Cyclase Activator Protein 5 from Zebrafish Photoreceptors. Biochemistry 2017, 56, 6652-6661. [CrossRef]

85. Shichi, H. Microsomal electron transfer system of bovine retinal pigment epithelium. Exp. Eye Res. 1969, 8 , 60-68. [CrossRef]

86. Yefimova, M.G.; Jeanny, J.-C.; Keller, N.; Sergeant, C.; Guillonneau, X.; Beaumont, C.; Courtois, Y. Impaired retinal iron homeostasis associated with defective phagocytosis in Royal College of Surgeons rats. Investig. Ophthalmol. Vis. Sci. 2002, 43, 537-545.

87. McGahan, M.C.; Harned, J.; Mukunnemkeril, M.; Goralska, M.; Fleisher, L.; Ferrell, J.B. Iron alters glutamate secretion by regulating cytosolic aconitase activity. Am. J. Physiol. Cell Physiol. 2005, 288, C1117-C1124. [CrossRef]

88. Kaushik, P.; Gorin, F.; Vali, S. Dynamics of tyrosine hydroxylase mediated regulation of dopamine synthesis. J. Comput. Neurosci. 2007, 22, 147-160. [CrossRef]

89. Huang, Q.; Hong, X.; Hao, Q. SNAP-25 is also an iron-sulfur protein. FEBS Lett. 2008, 582, 1431-1436. [CrossRef]

90. Molday, R.S. Insights into the Molecular Properties of ABCA4 and Its Role in the Visual Cycle and Stargardt Disease. In Progress in Molecular Biology and Translational Science; Elsevier: Amsterdam, The Netherlands, 2015; Volume 134, pp. 415-431. ISBN 978-0-12-801059-4.

91. Ueda, K.; Kim, H.J.; Zhao, J.; Song, Y.; Dunaief, J.L.; Sparrow, J.R. Iron promotes oxidative cell death caused by bisretinoids of retina. Proc. Natl. Acad. Sci. USA 2018, 115, 4963-4968. [CrossRef]

92. Lucius, R.; Sievers, J. Postnatal retinal ganglion cells in vitro: Protection against reactive oxygen species (ROS)-induced axonal degeneration by cocultured astrocytes. Brain Res. 1996, 743, 56-62. [CrossRef]

93. Kurz, T.; Karlsson, M.; Brunk, U.T.; Nilsson, S.E.; Frennesson, C. ARPE-19 retinal pigment epithelial cells are highly resistant to oxidative stress and exercise strict control over their lysosomal redox-active iron. Autophagy 2009, 5, 494-501. [CrossRef] [PubMed]

94. Rogers, B.S.; Symons, R.C.A.; Komeima, K.; Shen, J.; Xiao, W.; Swaim, M.E.; Gong, Y.Y.; Kachi, S.; Campochiaro, P.A. Differential sensitivity of cones to iron-mediated oxidative damage. Investig. Ophthalmol. Vis. Sci. 2007, 48, 438-445. [CrossRef] [PubMed]

95. Różanowski, B.; Burke, J.M.; Boulton, M.E.; Sarna, T.; Różanowska, M. Human RPE Melanosomes Protect from Photosensitized and Iron-Mediated Oxidation but Become Pro-oxidant in the Presence of Iron upon Photodegradation. Investig. Ophthalmol. Vis. Sci. 2008, 49, 2838-2847. [CrossRef] 
96. Akeo, K.; Hiramitsu, T.; Yorifuji, H.; Okisaka, S. Membranes of retinal pigment epithelial cells in vitro are damaged in the phagocytotic process of the photoreceptor outer segment discs peroxidized by ferrous ions. Pigment Cell Res. 2002, 15, 341-347. [CrossRef]

97. Harned, J.; Nagar, S.; McGahan, M.C. Hypoxia controls iron metabolism and glutamate secretion in retinal pigmented epithelial cells. Biochim. Biophys. Acta 2014, 1840, 3138-3144. [CrossRef]

98. Reiner, A.; Fitzgerald, M.E.C.; Del Mar, N.; Li, C. Neural control of choroidal blood flow. Prog. Retin. Eye Res. 2018, 64, 96-130. [CrossRef]

99. Imamura, T.; Hirayama, T.; Tsuruma, K.; Shimazawa, M.; Nagasawa, H.; Hara, H. Hydroxyl radicals cause fluctuation in intracellular ferrous ion levels upon light exposure during photoreceptor cell death. Exp. Eye Res. 2014, 129, 24-30. [CrossRef]

100. Guajardo, M.H.; Terrasa, A.M.; Catalá, A. Lipid-protein modifications during ascorbate-Fe2+ peroxidation of photoreceptor membranes: Protective effect of melatonin. J. Pineal Res. 2006, 41, 201-210. [CrossRef]

101. Hunt, R.C.; Handy, I.; Smith, A. Heme-mediated reactive oxygen species toxicity to retinal pigment epithelial cells is reduced by hemopexin. J. Cell. Physiol. 1996, 168, 81-86. [CrossRef]

102. Tian, Y.; He, Y.; Song, W.; Zhang, E.; Xia, X. Neuroprotective effect of deferoxamine on N-methyl-d-aspartate-induced excitotoxicity in RGC-5 cells. Acta Biochim. Biophys. Sin. (Shanghai) 2017, 49, 827-834. [CrossRef] [PubMed]

103. Thaler, S.; Fiedorowicz, M.; Rejdak, R.; Choragiewicz, T.J.; Sulejczak, D.; Stopa, P.; Zarnowski, T.; Zrenner, E.; Grieb, P.; Schuettauf, F. Neuroprotective effects of tempol on retinal ganglion cells in a partial optic nerve crush rat model with and without iron load. Exp. Eye Res. 2010, 90, 254-260. [CrossRef] [PubMed]

104. Wang, Z.J.; Lam, K.W.; Lam, T.T.; Tso, M.O. Iron-induced apoptosis in the photoreceptor cells of rats. Investig. Ophthalmol. Vis. Sci. 1998, 39, 631-633. [PubMed]

105. Daruich, A.; Le Rouzic, Q.; Jonet, L.; Naud, M.-C.; Kowalczuk, L.; Pournaras, J.-A.; Boatright, J.H.; Thomas, A.; Turck, N.; Moulin, A.; et al. Iron is neurotoxic in retinal detachment and transferrin confers neuroprotection. Sci. Adv. 2019, 5, eaau9940. [CrossRef]

106. Chaudhary, K.; Promsote, W.; Ananth, S.; Veeranan-Karmegam, R.; Tawfik, A.; Arjunan, P.; Martin, P.; Smith, S.B.; Thangaraju, M.; Kisselev, O.; et al. Iron Overload Accelerates the Progression of Diabetic Retinopathy in Association with Increased Retinal Renin Expression. Sci. Rep. 2018, 8, 3025. [CrossRef]

107. Totsuka, K.; Ueta, T.; Uchida, T.; Roggia, M.F.; Nakagawa, S.; Vavvas, D.G.; Honjo, M.; Aihara, M. Oxidative stress induces ferroptotic cell death in retinal pigment epithelial cells. Exp. Eye Res. 2019, 181, 316-324. [CrossRef]

108. Sun, Y.; Zheng, Y.; Wang, C.; Liu, Y. Glutathione depletion induces ferroptosis, autophagy, and premature cell senescence in retinal pigment epithelial cells. Cell Death Dis. 2018, 9, 753. [CrossRef]

109. Muckenthaler, M.U.; Rivella, S.; Hentze, M.W.; Galy, B. A Red Carpet for Iron Metabolism. Cell 2017, 168, 344-361. [CrossRef]

110. Gelfand, B.D.; Wright, C.B.; Kim, Y.; Yasuma, T.; Yasuma, R.; Li, S.; Fowler, B.J.; Bastos-Carvalho, A.; Kerur, N.; Uittenbogaard, A.; et al. Iron Toxicity in the Retina Requires Alu RNA and the NLRP3 Inflammasome. Cell Rep. 2015, 11, 1686-1693. [CrossRef]

111. Li, Y.; Song, D.; Song, Y.; Zhao, L.; Wolkow, N.; Tobias, J.W.; Song, W.; Dunaief, J.L. Iron-induced Local Complement Component 3 (C3) Up-regulation via Non-canonical Transforming Growth Factor (TGF)-beta Signaling in the Retinal Pigment Epithelium. J. Biol. Chem 2015, 290, 11918-11934. [CrossRef]

112. Vogi, W.; Nolte, R.; Brunahl, D. Binding of iron to the 5th component of human complement directs oxygen radical-mediated conversion to specific sites and causes nonenzymic activation. Complement Inflamm 1991, 8 , 313-319.

113. Toomey, C.B.; Johnson, L.V.; Bowes Rickman, C. Complement factor H in AMD: Bridging genetic associations and pathobiology. Prog. Retin. Eye Res. 2018, 62, 38-57. [CrossRef] [PubMed]

114. Asthana, A.; Baksi, S.; Ashok, A.; Karmakar, S.; Mammadova, N.; Kokemuller, R.; Greenlee, M.H.; Kong, Q.; Singh, N. Prion protein facilitates retinal iron uptake and is cleaved at the $\beta$-site: Implications for retinal iron homeostasis in prion disorders. Sci. Rep. 2017, 7, 9600. [CrossRef] [PubMed]

115. You, L.-H.; Yan, C.-Z.; Zheng, B.-J.; Ci, Y.-Z.; Chang, S.-Y.; Yu, P.; Gao, G.-F.; Li, H.-Y.; Dong, T.-Y.; Chang, Y.-Z. Astrocyte hepcidin is a key factor in LPS-induced neuronal apoptosis. Cell Death Dis. 2017, 8, e2676. [CrossRef] [PubMed] 
116. Gnana-Prakasam, J.P.; Martin, P.M.; Mysona, B.A.; Roon, P.; Smith, S.B.; Ganapathy, V. Hepcidin expression in mouse retina and its regulation via lipopolysaccharide/Toll-like receptor-4 pathway independent of Hfe. Biochem. J. 2008, 411, 79-88. [CrossRef] [PubMed]

117. Urrutia, P.J.; Hirsch, E.C.; González-Billault, C.; Núñez, M.T. Hepcidin attenuates amyloid beta-induced inflammatory and pro-oxidant responses in astrocytes and microglia. J. Neurochem. 2017, 142, 140-152. [CrossRef]

118. Ghosh, S.; Shang, P.; Yazdankhah, M.; Bhutto, I.; Hose, S.; Montezuma, S.R.; Luo, T.; Chattopadhyay, S.; Qian, J.; Lutty, G.A.; et al. Activating the AKT2-nuclear factor-kB-lipocalin-2 axis elicits an inflammatory response in age-related macular degeneration: Lipocalin-2 as an indicator of early AMD. J. Pathol. 2017, 241, 583-588. [CrossRef]

119. Coffman, L.G.; Brown, J.C.; Johnson, D.A.; Parthasarathy, N.; D’Agostino, R.B.; Lively, M.O.; Hua, X.; Tilley, S.L.; Muller-Esterl, W.; Willingham, M.C.; et al. Cleavage of high-molecular-weight kininogen by elastase and tryptase is inhibited by ferritin. Am. J. Physiol. Lung Cell Mol. Physiol. 2008, 294, L505-L515. [CrossRef]

120. Gnana-Prakasam, J.P.; Ananth, S.; Prasad, P.D.; Zhang, M.; Atherton, S.S.; Martin, P.M.; Smith, S.B.; Ganapathy, V. Expression and iron-dependent regulation of succinate receptor GPR91 in retinal pigment epithelium. Investig. Ophthalmol. Vis. Sci. 2011, 52, 3751-3758. [CrossRef]

121. Arjunan, P.; Gnanaprakasam, J.P.; Ananth, S.; Romej, M.A.; Rajalakshmi, V.-K.; Prasad, P.D.; Martin, P.M.; Gurusamy, M.; Thangaraju, M.; Bhutia, Y.D.; et al. Increased Retinal Expression of the Pro-Angiogenic Receptor GPR91 via BMP6 in a Mouse Model of Juvenile Hemochromatosis. Investig. Ophthalmol. Vis. Sci. 2016, 57, 1612-1619. [CrossRef]

122. Burke, J.M.; Smith, J.M. Retinal proliferation in response to vitreous hemoglobin or iron. Investig. Ophthalmol. Vis. Sci. 1981, 20, 582-592. [PubMed]

123. Loporchio, D.; Mukkamala, L.; Gorukanti, K.; Zarbin, M.; Langer, P.; Bhagat, N. Intraocular foreign bodies: A review. Surv. Ophthalmol. 2016, 61, 582-596. [CrossRef] [PubMed]

124. Konerirajapuram, N.S.; Coral, K.; Punitham, R.; Sharma, T.; Kasinathan, N.; Sivaramakrishnan, R. Trace elements iron, copper and zinc in vitreous of patients with various vitreoretinal diseases. Indian J. Ophthalmol. 2004, 52, 145-148. [PubMed]

125. Conart, J.-B.; Berrod, J.-P. [Non-traumatic vitreous hemorrhage]. J. Fr. Ophtalmol. 2016, 39, $219-225$. [CrossRef] [PubMed]

126. Levin, A.V. Retinal hemorrhage in abusive head trauma. Pediatrics 2010, 126, 961-970. [CrossRef]

127. Casini, G.; Loiudice, P.; Menchini, M.; Sartini, F.; De Cillà, S.; Figus, M.; Nardi, M. Traumatic submacular hemorrhage: Available treatment options and synthesis of the literature. Int. J. Retin. Vitr. 2019, 5, 48. [CrossRef]

128. Bhisitkul, R.B.; Winn, B.J.; Lee, O.-T.; Wong, J.; de Souza Pereira, D.; Porco, T.C.; He, X.; Hahn, P.; Dunaief, J.L. Neuroprotective effect of intravitreal triamcinolone acetonide against photoreceptor apoptosis in a rabbit model of subretinal hemorrhage. Investig. Ophthalmol. Vis. Sci. 2008, 49, 4071-4077. [CrossRef]

129. Chen-Roetling, J.; Regan, K.A.; Regan, R.F. Protective effect of vitreous against hemoglobin neurotoxicity. Biochem. Biophys. Res. Commun. 2018, 503, 152-156. [CrossRef]

130. Zerbib, J.; Pierre-Kahn, V.; Sikorav, A.; Oubraham, H.; Sayag, D.; Lobstein, F.; Massonnet-Castel, S.; Haymann-Gawrilow, P.; Souied, E.H. Unusual retinopathy associated with hemochromatosis. Retin Cases Brief Rep. 2015, 9, 190-194. [CrossRef]

131. Gnana-Prakasam, J.P.; Tawfik, A.; Romej, M.; Ananth, S.; Martin, P.M.; Smith, S.B.; Ganapathy, V. Iron-mediated retinal degeneration in haemojuvelin-knockout mice. Biochem. J. 2012, 441, 599-608. [CrossRef]

132. Kumar, P.; Nag, T.C.; Jha, K.A.; Dey, S.K.; Kathpalia, P.; Maurya, M.; Gupta, C.L.; Bhatia, J.; Roy, T.S.; Wadhwa, S. Experimental oral iron administration: Histological investigations and expressions of iron handling proteins in rat retina with aging. Toxicology 2017, 392, 22-31. [CrossRef]

133. Shu, W.; Dunaief, J.L. Potential Treatment of Retinal Diseases with Iron Chelators. Pharmaceuticals (Basel) 2018, 11, 112. [CrossRef] [PubMed]

134. Wong, W.L.; Su, X.; Li, X.; Cheung, C.M.G.; Klein, R.; Cheng, C.-Y.; Wong, T.Y. Global prevalence of age-related macular degeneration and disease burden projection for 2020 and 2040: A systematic review and meta-analysis. Lancet Glob. Health 2014, 2, e106-e116. [CrossRef] 
135. Handa, J.T.; Bowes Rickman, C.; Dick, A.D.; Gorin, M.B.; Miller, J.W.; Toth, C.A.; Ueffing, M.; Zarbin, M.; Farrer, L.A. A systems biology approach towards understanding and treating non-neovascular age-related macular degeneration. Nat. Commun. 2019, 10, 3347. [CrossRef] [PubMed]

136. Biesemeier, A.; Yoeruek, E.; Eibl, O.; Schraermeyer, U. Iron accumulation in Bruch's membrane and melanosomes of donor eyes with age-related macular degeneration. Exp. Eye Res. 2015, 137, $39-49$. [CrossRef]

137. Hahn, P.; Milam, A.H.; Dunaief, J.L. Maculas Affected by Age-Related Macular Degeneration Contain Increased Chelatable Iron in the Retinal Pigment Epithelium and Bruch's Membrane. Arch. Ophthalmol. 2003, 121, 1099-1105. [CrossRef]

138. Junemann, A.G.; Stopa, P.; Michalke, B.; Chaudhri, A.; Reulbach, U.; Huchzermeyer, C.; Schlotzer-Schrehardt, U.; Kruse, F.E.; Zrenner, E.; Rejdak, R. Levels of aqueous humor trace elements in patients with non-exsudative age-related macular degeneration: A case-control study. PLoS ONE 2013, 8, e56734. [CrossRef]

139. Dentchev, T.; Hahn, P.; Dunaief, J.L. Strong labeling for iron and the iron-handling proteins ferritin and ferroportin in the photoreceptor layer in age-related macular degeneration. Arch Ophthalmol. 2005, 123, 1745-1746. [CrossRef]

140. Chowers, I.; Wong, R.; Dentchev, T.; Farkas, R.H.; Iacovelli, J.; Gunatilaka, T.L.; Medeiros, N.E.; Presley, J.B.; Campochiaro, P.A.; Curcio, C.A.; et al. The iron carrier transferrin is upregulated in retinas from patients with age-related macular degeneration. Investig. Ophthalmol. Vis. Sci. 2006, 47, 2135-2140. [CrossRef]

141. Čolak, E.; Žorić, L.; Radosavljević, A.; Ignjatović, S. The Association of Serum Iron-Binding Proteins and the Antioxidant Parameter Levels in Age-Related Macular Degeneration. Curr. Eye Res. 2018, 43, 659-665. [CrossRef]

142. Wysokinski, D.; Danisz, K.; Pawlowska, E.; Dorecka, M.; Romaniuk, D.; Robaszkiewicz, J.; Szaflik, M.; Szaflik, J.; Blasiak, J.; Szaflik, J.P. Transferrin receptor levels and polymorphism of its gene in age-related macular degeneration. Acta Biochim. Pol. 2015, 62, 177-184. [CrossRef] [PubMed]

143. Synowiec, E.; Pogorzelska, M.; Blasiak, J.; Szaflik, J.; Szaflik, J.P. Genetic polymorphism of the iron-regulatory protein-1 and -2 genes in age-related macular degeneration. Mol. Biol. Rep. 2012, 39, 7077-7087. [CrossRef] [PubMed]

144. Synowiec, E.; Szaflik, J.; Chmielewska, M.; Wozniak, K.; Sklodowska, A.; Waszczyk, M.; Dorecka, M.; Blasiak, J.; Szaflik, J.P. An association between polymorphism of the heme oxygenase-1 and -2 genes and age-related macular degeneration. Mol. Biol. Rep. 2012, 39, 2081-2087. [CrossRef] [PubMed]

145. Szemraj, M.; Oszajca, K.; Szemraj, J.; Jurowski, P. MicroRNA Expression Analysis in Serum of Patients with Congenital Hemochromatosis and Age-Related Macular Degeneration (AMD). Med. Sci. Monit. 2017, 23, 4050-4060. [CrossRef] [PubMed]

146. Ding, J.; Wong, T.Y. Current epidemiology of diabetic retinopathy and diabetic macular edema. Curr. Diab. Rep. 2012, 12, 346-354. [CrossRef] [PubMed]

147. Ciudin, A.; Hernández, C.; Simó, R. Iron overload in diabetic retinopathy: A cause or a consequence of impaired mechanisms? Exp. Diabetes Res. 2010, 2010, 714108. [CrossRef]

148. Baumann, B.; Sterling, J.; Song, Y.; Song, D.; Fruttiger, M.; Gillies, M.; Shen, W.; Dunaief, J.L. Conditional Müller Cell Ablation Leads to Retinal Iron Accumulation. Investig. Ophthalmol. Vis. Sci. 2017, 58, 4223-4234. [CrossRef]

149. Weinreb, R.N.; Aung, T.; Medeiros, F.A. The pathophysiology and treatment of glaucoma: A review. JAMA 2014, 311, 1901-1911. [CrossRef]

150. Wang, H.-W.; Sun, P.; Chen, Y.; Jiang, L.-P.; Wu, H.-P.; Zhang, W.; Gao, F. Research progress on human genes involved in the pathogenesis of glaucoma (Review). Mol. Med. Rep. 2018, 18, 656-674. [CrossRef]

151. Tripathi, R.C.; Borisuth, N.S.; Tripathi, B.J.; Gotsis, S.S. Quantitative and qualitative analyses of transferrin in aqueous humor from patients with primary and secondary glaucomas. Investig. Ophthalmol. Vis. Sci. 1992, 33, 2866-2873.

152. Farkas, R.H.; Chowers, I.; Hackam, A.S.; Kageyama, M.; Nickells, R.W.; Otteson, D.C.; Duh, E.J.; Wang, C.; Valenta, D.F.; Gunatilaka, T.L.; et al. Increased expression of iron-regulating genes in monkey and human glaucoma. Investig. Ophthalmol. Vis. Sci. 2004, 45, 1410-1417. [CrossRef] [PubMed] 
153. Hohberger, B.; Chaudhri, M.A.; Michalke, B.; Lucio, M.; Nowomiejska, K.; Schlötzer-Schrehardt, U.; Grieb, P.; Rejdak, R.; Jünemann, A.G.M. Levels of aqueous humor trace elements in patients with open-angle glaucoma. J. Trace Elem. Med. Biol. 2018, 45, 150-155. [CrossRef] [PubMed]

154. Fick, A.; Jünemann, A.; Michalke, B.; Lucio, M.; Hohberger, B. Levels of serum trace elements in patients with primary open-angle glaucoma. J. Trace Elem. Med. Biol. 2019, 53, 129-134. [CrossRef] [PubMed]

155. Lin, S.-C.; Wang, S.Y.; Yoo, C.; Singh, K.; Lin, S.C. Association between serum ferritin and glaucoma in the South Korean population. JAMA Ophthalmol. 2014, 132, 1414-1420. [CrossRef] [PubMed]

156. Sarnat-Kucharczyk, M.; Rokicki, W.; Zalejska-Fiolka, J.; Pojda-Wilczek, D.; Mrukwa-Kominek, E. Determination of Serum Ceruloplasmin Concentration in Patients with Primary Open Angle Glaucoma with Cataract and Patients with Cataract Only: A Pilot Study. Med. Sci. Monit. 2016, 22, 1384-1388. [CrossRef] [PubMed]

157. DeToma, A.S.; Dengler-Crish, C.M.; Deb, A.; Braymer, J.J.; Penner-Hahn, J.E.; van der Schyf, C.J.; Lim, M.H.; Crish, S.D. Abnormal metal levels in the primary visual pathway of the DBA/2J mouse model of glaucoma. Biometals 2014, 27, 1291-1301. [CrossRef]

158. Anders, F.; Teister, J.; Funke, S.; Pfeiffer, N.; Grus, F.; Solon, T.; Prokosch, V. Proteomic profiling reveals crucial retinal protein alterations in the early phase of an experimental glaucoma model. Graefes Arch. Clin. Exp. Ophthalmol. 2017, 255, 1395-1407. [CrossRef]

159. Cheah, J.H.; Kim, S.F.; Hester, L.D.; Clancy, K.W.; Patterson, S.E.; Papadopoulos, V.; Snyder, S.H. NMDA receptor-nitric oxide transmission mediates neuronal iron homeostasis via the GTPase Dexras1. Neuron 2006, 51, 431-440. [CrossRef]

160. Liu, P.; Zhang, M.; Shoeb, M.; Hogan, D.; Tang, L.; Syed, M.F.; Wang, C.Z.; Campbell, G.A.; Ansari, N.H. Metal chelator combined with permeability enhancer ameliorates oxidative stress-associated neurodegeneration in rat eyes with elevated intraocular pressure. Free Radic. Biol. Med. 2014, 69, 289-299. [CrossRef]

161. Sakamoto, K.; Suzuki, T.; Takahashi, K.; Koguchi, T.; Hirayama, T.; Mori, A.; Nakahara, T.; Nagasawa, H.; Ishii, K. Iron-chelating agents attenuate NMDA-Induced neuronal injury via reduction of oxidative stress in the rat retina. Exp. Eye Res. 2018, 171, 30-36. [CrossRef]

162. Sirohi, K.; Chalasani, M.L.S.; Sudhakar, C.; Kumari, A.; Radha, V.; Swarup, G. M98K-OPTN induces transferrin receptor degradation and RAB12-mediated autophagic death in retinal ganglion cells. Autophagy 2013, 9, 510-527. [CrossRef] [PubMed]

163. Hamel, C. Retinitis pigmentosa. Orphanet. J. Rare Dis. 2006, 1, 40. [CrossRef] [PubMed]

164. Picard, E.; Jonet, L.; Sergeant, C.; Vesvres, M.H.; Behar-Cohen, F.; Courtois, Y.; Jeanny, J.C. Overexpressed or intraperitoneally injected human transferrin prevents photoreceptor degeneration in rd10 mice. Mol. Vis. 2010, 16, 2612-2625. [PubMed]

165. Scerri, T.S.; Quaglieri, A.; Cai, C.; Zernant, J.; Matsunami, N.; Baird, L.; Scheppke, L.; Bonelli, R.; Yannuzzi, L.A.; Friedlander, M.; et al. Genome-wide analyses identify common variants associated with macular telangiectasia type 2. Nat. Genet. 2017, 49, 559-567. [CrossRef] [PubMed]

166. Obolensky, A.; Berenshtein, E.; Lederman, M.; Bulvik, B.; Alper-Pinus, R.; Yaul, R.; Deleon, E.; Chowers, I.; Chevion, M.; Banin, E. Zinc-desferrioxamine attenuates retinal degeneration in the rd10 mouse model of retinitis pigmentosa. Free Radic. Biol. Med. 2011, 51, 1482-1491. [CrossRef]

167. Li, Z.L.; Lam, S.; Tso, M.O. Desferrioxamine ameliorates retinal photic injury in albino rats. Curr. Eye Res. 1991, 10, 133-144. [CrossRef]

168. Hadziahmetovic, M.; Song, Y.; Wolkow, N.; Iacovelli, J.; Grieco, S.; Lee, J.; Lyubarsky, A.; Pratico, D.; Connelly, J.; Spino, M.; et al. The Oral Iron Chelator Deferiprone Protects against Iron Overload-Induced Retinal Degeneration. Investig. Ophthalmol. Vis. Sci. 2011, 52, 959-968. [CrossRef]

169. Song, D.; Zhao, L.; Li, Y.; Hadziahmetovic, M.; Song, Y.; Dunaief, J.L. The oral iron chelator deferiprone protects against iron overload-induced retinal degeneration in Hepcidin knockout mice. Investig. Ophthalmol. Vis. Sci. 2014, 55, 4525-4532. [CrossRef]

170. Song, D.; Song, Y.; Hadziahmetovic, M.; Zhong, Y.; Dunaief, J.L. Systemic administration of the iron chelator deferiprone protects against light-induced photoreceptor degeneration in the mouse retina. Free Radic. Biol. Med. 2012, 53, 64-71. [CrossRef]

171. Hadziahmetovic, M.; Pajic, M.; Grieco, S.; Song, Y.; Song, D.; Li, Y.; Cwanger, A.; Iacovelli, J.; Chu, S.; Ying, G.-S.; et al. The Oral Iron Chelator Deferiprone Protects Against Retinal Degeneration Induced through Diverse Mechanisms. Transl. Vis. Sci. Technol. 2012, 1, 7. [CrossRef] 
172. Arora, A.; Wren, S.; Gregory Evans, K. Desferrioxamine related maculopathy: A case report. Am. J. Hematol. 2004, 76, 386-388. [CrossRef] [PubMed]

173. Lakhanpal, V.; Schocket, S.S.; Jiji, R. Deferoxamine (Desferal)-induced toxic retinal pigmentary degeneration and presumed optic neuropathy. Ophthalmology 1984, 91, 443-451. [CrossRef]

174. Jauregui, R.; Park, K.S.; Bassuk, A.G.; Mahajan, V.B.; Tsang, S.H. Deferoxamine-induced electronegative ERG responses. Doc. Ophthalmol. 2018, 137, 15-23. [CrossRef] [PubMed]

175. Mobarra, N.; Shanaki, M.; Ehteram, H.; Nasiri, H.; Sahmani, M.; Saeidi, M.; Goudarzi, M.; Pourkarim, H.; Azad, M. A Review on Iron Chelators in Treatment of Iron Overload Syndromes. Int. J. Hematol. Oncol. Stem Cell Res. 2016, 10, 239-247. [PubMed]

176. Sahlstedt, L.; von Bonsdorff, L.; Ebeling, F.; Ruutu, T.; Parkkinen, J. Effective binding of free iron by a single intravenous dose of human apotransferrin in haematological stem cell transplant patients. Br. J. Haematol. 2002, 119, 547-553. [CrossRef]

177. Brittenham, G.M. Iron-chelating therapy for transfusional iron overload. N. Engl. J. Med. 2011, 364, $146-156$. [CrossRef]

178. Goya, N.; Miyazaki, S.; Kodate, S.; Ushio, B. A family of congenital atransferrinemia. Blood 1972, 40, $239-245$. [CrossRef]

179. Simon, S.; Athanasiov, P.A.; Jain, R.; Raymond, G.; Gilhotra, J.S. Desferrioxamine-related ocular toxicity: A case report. Indian J. Ophthalmol. 2012, 60, 315-317. [CrossRef]

180. Di Nicola, M.; Barteselli, G.; Dell'Arti, L.; Ratiglia, R.; Viola, F. Functional and Structural Abnormalities in Deferoxamine Retinopathy: A Review of the Literature. Biomed. Res. Int. 2015, 2015, 249617. [CrossRef]

181. Beau-Salinas, F.; Guitteny, M.A.; Donadieu, J.; Jonville-Bera, A.P.; Autret-Leca, E. High doses of deferiprone may be associated with cerebellar syndrome. BMJ 2009, 338, a2319. [CrossRef]

182. Mehdizadeh, M.; Nowroozzadeh, M.H. Posterior subcapsular opacity in two patients with thalassaemia major following deferiprone consumption. Clin. Exp. Optom. 2009, 92, 392-394. [CrossRef]

183. Taneja, R.; Malik, P.; Sharma, M.; Agarwal, M.C. Multiple transfused thalassemia major: Ocular manifestations in a hospital-based population. Indian J. Ophthalmol. 2010, 58, 125-130. [PubMed]

184. Masera, N.; Rescaldani, C.; Azzolini, M.; Vimercati, C.; Tavecchia, L.; Masera, G.; De Molfetta, V.; Arpa, P. Development of lens opacities with peculiar characteristics in patients affected by thalassemia major on chelating treatment with deferasirox (ICL670) at the Pediatric Clinic in Monza, Italy. Haematologica 2008, 93, e9-e10. [CrossRef] [PubMed]

185. Pan, Y.; Keane, P.A.; Sadun, A.A.; Fawzi, A.A. Optical coherence tomography findings in deferasirox-related maculopathy. Retin Cases Brief Rep. 2010, 4, 229-232. [CrossRef]

186. Farajipour, H.; Rahimian, S.; Taghizadeh, M. Curcumin: A new candidate for retinal disease therapy? J. Cell. Biochem. 2018, 120, 6886-6893. [CrossRef]

187. Majumdar, S.; Srirangam, R. Potential of the Bioflavonoids in the Prevention/Treatment of Ocular Disorders. J. Pharm. Pharmacol. 2010, 62, 951-965. [CrossRef] [PubMed]

188. Voigt, A.P.; Whitmore, S.S.; Flamme-Wiese, M.J.; Riker, M.J.; Wiley, L.A.; Tucker, B.A.; Stone, E.M.; Mullins, R.F.; Scheetz, T.E. Molecular characterization of foveal versus peripheral human retina by single-cell RNA sequencing. Exp. Eye Res. 2019, 184, 234-242. [CrossRef]

189. Qian, Z.M.; Li, H.; Sun, H.; Ho, K. Targeted drug delivery via the transferrin receptor-mediated endocytosis pathway. Pharm. Rev. 2002, 54, 561-587. [CrossRef]

190. Gomme, P.T.; McCann, K.B.; Bertolini, J. Transferrin: Structure, function and potential therapeutic actions. Drug Discov. Today 2005, 10, 267-273. [CrossRef]

191. de Jong, P.T.V.M. A Historical Analysis of the Quest for the Origins of Aging Macula Disorder, the Tissues Involved, and Its Terminology. Ophthalmol. Eye. Dis. 2016, 8, 5-14. [CrossRef]

192. Weber, C.; Cole, D.J.; O’Regan, D.D.; Payne, M.C. Renormalization of myoglobin-ligand binding energetics by quantum many-body effects. PNAS 2014, 111, 5790-5795. [CrossRef] [PubMed]

(C) 2020 by the authors. Licensee MDPI, Basel, Switzerland. This article is an open access article distributed under the terms and conditions of the Creative Commons Attribution (CC BY) license (http://creativecommons.org/licenses/by/4.0/). 